\title{
PRUDENTIAL REGULATORY REGIMES, ACCOUNTING STANDARDS, AND EARNINGS MANAGEMENT IN THE BANKING INDUSTRY
}

\author{
Ali Ashraf1', M. Kabir Hassan², Kyle J. Putnam³, Arja Turunen-Red ${ }^{4}$ \\ ${ }^{1}$ Department of Marketing \& Finance, Frostburg State University, Maryland, USA. \\ Email: aashraf@frostburg.edu \\ ${ }^{2}$ Department of Economics \& Finance, University of New Orleans, Los Angeles, USA. \\ Email: KabirHassan@Cox.net \\ ${ }^{3}$ Business Department, Linfield College, Oregon, USA. Email: putnamk@gmail.com \\ ${ }^{4}$ Department of Economics and Finance, University of New Orleans, Los Angeles, USA. \\ Email: aturunen@uno.edu
}

\begin{abstract}
We analyze if a change in accounting standard or a change in prudential regulation impacts banks' loan loss provision. We find that, in general, the banks using a principles-based accounting standard exhibit a lower level of earnings management compared to banks using a rules-based accounting standard. When a country moves from pro-cyclical macro-prudential regulations to a dynamic provisioning regime, banks are more likely to set aside a larger amount of loan loss provision for the purpose of income smoothing.
\end{abstract}

Keywords: Accounting standard; Banks; Loan loss provision.

JEL Classification: E580; G210; G280.

Article history:

Received : September 12, 2018

Revised : December 10, 2018

Accepted : December 11, 2018

Available online : January 30, 2019

https://doi.org/10.21098/bemp.v21i3.975 


\section{INTRODUCTION}

Existing literature presents mixed empirical results on banks' use of Loan Loss Provision (LLP) as a tool for earnings management (Laeven and Majnoni, 2003; Hasan and Wall, 2004; Bikker and Metzemakers, 2005; Fonseca and Gonzalez, 2008). Earnings management arises through a bank's assessment of its expected loan losses and the subsequent subjective determination of LLP. The inherent subjectivity of the LLP process allows bank management to pursue other motivations that existing literature typically identifies as: income smoothening, capital management, or earnings signaling (Wahlen, 1994; Ahmed, Takeda, and Thomas, 1999; Anandarajan,, Hassan, and Lozano-Vivas, 2003; and Das and Ghosh, 2007).

Banks' earnings management is a well-researched topic in the finance literature, but recent developments in macro-prudential regulation and changes in accounting standards have prompted further research into the potential for earnings management through LLP. The Norwalk agreement between the Financial Accounting Standards Board (FASB) and the International Accounting Standards Board (IASB) signed in September 2002 is an important milestone in accounting regulations. The agreement creates a convergence of two dominant accounting standards, the rules-based US Generally Accepted Accounting Principles (GAAP) and the principles-based International Financial Reporting Standards (IFRS), in order to more fully support healthy global capital markets. The new, and arguably superior, reporting standards will dramatically affect the manner in which banks can recognize losses using their main operating accrual item-LLP.

Additionally, as a follow-up to the 2007 Global Financial Crisis (GFC), central banks across the globe are re-thinking their prudential regulatory frameworks that define the procedures and formulas that govern the amount of LLP bank managers need to set aside to buffer for potential loan losses.

Macro-prudential regulations are of two broad categories: pro-cyclical and dynamic provisioning. In a pro-cyclical framework, which most countries pursue, the central bank sets a specified percentile of Risk Weighted Assets (RWA) to be maintained as LLP. One of the challenges of this framework is that during downturns in the business cycle, asset quality typically decreases, thus requiring managers to set aside more LLP. Such a provision tends to be counter-effective for central banks whose goal is to inject liquidity into the banking system. The GFC illustrated how excessive pro-cyclicality in the banking industry can amplify the business cycle through macro-financial linkages, which in turn has large negative spillover effects into the real economy (Panetta, Angelin, Albertazzi, Columba, DiCesare, Pilati, Salleo, and Santini, 2009). This challenge of the pro-cyclical framework leads to the alternative, known as dynamic provisioning, where LLP is determined through a formula that updates with business cycle information such that LLP would act as a counter-cyclical capital buffer. Essentially, banks gradually build loan loss revenue during the boom phase of the cycle and use this surplus during the economic downturn to cover excessive losses (Balla and McKenna, 2009; Carbó-Valverde and Rodríguez-Fernández, 2010; Chan-Lau, 2012; Pérez, Salas-Fumás, and Saurina 2011; and Burroni, Quagliariello, Sabatini, and Tola 2009). 
Bouvatier, Lepetit, and Strobel (2014), and Gebhardt and Novotny-Farkas (2011) thoroughly analyze the impacts of a change in regimes and accounting standards for European commercial banks. Specifically, Bouvatier et al. (2014) examine if bank ownership structure and country regulatory factors in a given regime influence bank income smoothing behavior. They find that banks with higher ownership concentrations are most likely to use LLP to smooth income, but the degree of earnings management is less obvious in countries that have strong regulatory regimes and higher external audit quality.

Gebhardt and Novotny-Farkas (2011), on the other hand, analyze the impact of mandatory IFRS adoption on listed European banks' accounting quality. Under the new standards set forth by IFRS, banks can only recognize incurred losses, as opposed to expected future losses, as of the balance sheet date via rule International Accounting Standards (IAS) 39. Such a change from GAAP regulations strictly limits the ability of managers to use LLP in the pursuit of other motivations. Consequently, this stricter accounting method under IAS 39 significantly reduces income smoothing.

Our paper complements the contemporary work of Bouvatier et al. (2014) and Gebhardt and Novotny-Farkas (2011) by analyzing how a joint change in bank accounting standards and a change in macro-prudential framework may affect the discretionary use of LLP for income smoothing, capital management, or earnings signaling for an international sample of banking institutions, rather than a single region. More specifically, we examine how competing regulatory frameworks affect the various motivations associated with managerial discretion over banks' main accrual item, LLP; the cross-country framework allows for robust findings from the panel dataset. We ask a set of specific questions accordingly. Do changes in the macro-prudential environment (from pro-cyclical to dynamic provisioning) affect the motivation for earnings management of LLP? Do changes in bank accounting standards have an effect on the motivation for earnings management of LLP? What is the joint impact on the motivation for earnings management of LLP if banks are obligated to operate in both a changing prudential regulatory and accounting standard regime?

Our research question necessitates a large sample of national banks in both pro-cyclical and dynamic regimes. We analyze data for 7,343 individual banks that belong to 118 countries over the period 1999 to 2010 . We find that, in general, bank managers use LLP to manage earnings for two purposes: income smoothening and capital management. We find no significant evidence in favor of the signaling hypothesis. If a country moves from a pro-cyclical to a dynamic provisioning regime, bank managers pursuing an income smoothing motive will generally set aside a larger amount of LLP. Regarding accounting standards, banks under principles-based accounting standards generally exhibit a lower overall level of earnings management compared to their rules-based counterparts. Finally, if a country undergoes a prudential regulation and accounting standard change simultaneously, the combined impact on managerial motivation for LLP is not statistically significantly different from banks in countries with existing conventional regulatory regimes or accounting standards. 
The remainder of the paper is as follows. Section II reviews the literature. Section III outlines the methodology. Section IV presents the descriptive statistics. Section V presents the regression results. Section VI provides concluding remarks.

\section{LITERATURE REVIEW}

A. Loan Loss Provisioning and Bank Earnings Management

Banks' incentives for using LLP as an earnings management tool depends on its financial performance, earnings volatility, and the need to build capital reserves. Bank managers weigh the trade-offs of earnings management tactics as higher provisions result in lower profits but create a safety net against future loan losses. In contrast, a lower level of provision increases reported profits but requires banks to use its capital reserves to cover larger than expected losses (Ahmed et al., 1999; and Fan and Wong, 2002).

Prior literature generally identifies three major explanations as to why bank managers pursue earnings management via LLP. First, the income smoothing hypothesis contends that during favorable economic times, managers keep extra provision that they can use as a cushion during a down turn in the business cycle to cover higher loan losses. Wahlen (1994) and Beaver and Engle (1996) present empirical evidence supporting this explanation. They show that LLP are positively related to bank pretax and provision earnings (EBTP). Second, proponents of the capital management hypothesis argue that bank managers can use LLP reserves as part of their minimum capital requirement when facing any capital shortfall; Das and Ghosh (2007) find a significantly negative relationship between LLP and bank capital that supports this supposition. Third, the earnings signaling hypothesis contends that managers may use higher LLP as a means of conveying better financial strength. If a bank, for instance, wants to signal its strength about future earnings when the market perceives its value as low, the bank will increase LLP to indicate its ability to absorb future potential losses. Accordingly, LLP is positively related to changes in earnings or future investment opportunities (Wahlen, 1994; Beaver and Engle, 1996).

\section{B. Accounting Standards and Loan Loss Provisioning}

Following the Norwalk agreement between the FASB and IASB in 2002, a number of studies emphasize the implications of the convergence of accounting standards, particularly in non-financial firms. Psaros and Trotman (2004) find a lower degree of earnings management when firms use a principles-based standard rather a rulesbased standard. Research by Bartov, Goldberg, and Kim (2005) and Hung and Subramanyam (2007) highlight the major financial statement effects of adopting different accounting standards that could play a role in earnings management decisions for managers.

Following the enactment of the Sarbanes-Oxley Act, in 2002, many firms switched from accounting decisions to transaction decisions, suggesting that earnings management choices depend on the discretion given under different accounting standards (Cohen, Dey, and Lys, 2008). Interestingly, Beest (2009) shows that either of the accounting standards lead to a comparable levels of 
earnings management. However, managers using rules-based standards engage in earnings management through transaction decisions, while managers using principles-based standards engage in activity through accounting decisions.

More recently, Zhou, Xiong, Ganguli (2010) investigate whether changes in accounting standard add any value to accounting information in a transitional economy, such as China. They find that firms following IAS usually recognize losses in a timelier manner and smooth earnings less than firms adopting local GAAP. These findings resemble those of Gebhardt and Novotny-Farkas (2011). Capkun, Jeny, Jeanjean, and Weiss (2010) use a dataset of 1,635 European Union firms that went through mandatory transition from local GAAP to IFRS during the 2004-2005 timeframe and examine the flexibility of the IFRS standard and find that local GAAP firms with negative earnings generally show positive earnings reconciliations.

\section{Pro-cyclicality in Prudential Regulatory Regimes}

Prudential regulations provide explicit guidelines regarding the manner in which bank managers are to classify their loan portfolios. These regulations, for instance, dictate how much managers are to set aside from bank earnings based on a weighted loan-delinquency risk matrix. Prudential regulations are particularly important for the banking industry as the firms deal with depositor investments, and at times, may be highly leveraged. Further, loan delinquency rates increase during financial crises or economic recessions and this in turn affects banks' capital adequacy and the ability to lend. The financial soundness of the industry is vitally important to the overall economy and is accordingly subject to high regulatory oversight. Bouvatier et al., 2014 find robust evidence that countries with strong regimes reduce earnings management behavior, and in particular income smoothing activities.

Spanish financial regulators were the first to initiate the concept of dynamic provisioning in 2002 as an alternative prudential framework that requires banks to maintain a LLP requirement by using a model that provides forward-looking business cycle forecasts. Following Spain's regulatory change, financial regulators in other countries, such as Chile, Colombia, and Peru have also initiated similar approaches in 2003, 2007, and 2009, respectively, with some minor variations to adjust for country-specific factors. The issues underlying a dynamic provisioning regime are still evolving under the prudential framework; hence, the debate on whether pro-cyclical or dynamic provisioning is the solution to the problems facing many banks is far from settled (Bouvatier and Lepetit, 2008; Wezel, 2010; Bouvatier and Lepetit, 2012; Chan-Lau, 2012).

\section{METHODOLOGY}

\section{A. Variable Definitions}

Cross-country empirical studies on LLP generally control for country-specific macroeconomic variables; namely, per capita GDP, per capita GDP growth, and inflation rate (La Porta, Lopez-de-Silanes, and Shleifer, 2008-hereafter LLS, 2008). Recent studies also acknowledge the role of country regulatory and legal 
frameworks, level of investor protections, and financial development (La Porta, Lopez-de-Silanes, Shleifer, and Vishny (1997) - hereafter LLSV, 1997; Fonseca and González, 2008). Regarding bank characteristics, asset size (measured in logs) is typically used as a control variable in the LLP literature (Bikker and Metzemakers, 2005). Accordingly, we include these country-specific and bank-specific control variables.

Table 1.

Variable Description and Data Sources

This table reports a description of the data set including variable names (column 1), variable description (column 2), data source (column 3) and expected sign (column 4).

\begin{tabular}{|c|c|c|c|}
\hline Variable Name & Variable Description & Data Source & Expected Sign \\
\hline \multicolumn{4}{|c|}{ Dependent Variable } \\
\hline$L L P_{i, t}$ & $\begin{array}{l}\text { Ratio of LLP over one-period } \\
\text { lag of total assets }\end{array}$ & BankScope & \\
\hline \multicolumn{4}{|c|}{ Bank Characteristics } \\
\hline$L L P_{i,(t-1)}$ & Lag of the dependent variable & BankScope & $\begin{array}{c}+ \\
+ \\
\text { (pro-cyclical) }\end{array}$ \\
\hline$C R A R_{i,(t-1)}$ & $\begin{array}{l}\text { Required Tier-I capital, normalized by } \\
\text { risk-weighted assets (RWA) }\end{array}$ & BankScope & $\begin{array}{c}- \\
\text { (capital } \\
\text { management) }\end{array}$ \\
\hline$E B T P_{i, t}$ & $\begin{array}{l}\text { Earnings before tax and provisions over } \\
\text { one-period lag of total assets }\end{array}$ & BankScope & $\begin{array}{c}+ \\
\text { (income } \\
\text { smoothing) }\end{array}$ \\
\hline$\triangle E B T P_{i,(t-1)}$ & $\begin{array}{c}\text { Change in earnings before tax and } \\
\text { provisions over one-period lag of total } \\
\text { assets }\end{array}$ & BankScope & $\begin{array}{c}+ \\
+ \\
\text { (earnings } \\
\text { signaling) }\end{array}$ \\
\hline \multicolumn{4}{|c|}{ Prudential Regulation Indicator } \\
\hline DynDum & $\begin{array}{l}\text { Equal to } 1 \text { if country is implementing } \\
\text { dynamic provisioning, } 0 \text { otherwise }\end{array}$ & & $\begin{array}{l}\text { Opposite/not } \\
\text { significant }\end{array}$ \\
\hline \multicolumn{4}{|c|}{ Accounting Standard Indicator } \\
\hline PrincDum & $\begin{array}{c}\text { Equal to } 1 \text { if a bank uses a principles- } \\
\text { based accounting standard, } 0 \text { otherwise }\end{array}$ & & $\begin{array}{c}\text { Opposite/not } \\
\text { significant }\end{array}$ \\
\hline \multicolumn{4}{|l|}{ Bank Control } \\
\hline LNTA & Natural log of bank total assets & BankScope & \\
\hline \multicolumn{4}{|c|}{ Macroeconomic Controls } \\
\hline PCGDP & Real GDP in billions of dollars per capita & IMF & \\
\hline PCGDPG & Real growth in per capita GDP & IMF & \\
\hline INFL & Annual inflation growth & IMF & \\
\hline \multicolumn{4}{|c|}{ Regulatory/Legal Controls } \\
\hline DISCL & Accounting disclosure index & LLS (2008) & \\
\hline PRIVO & Ratio of private credit to GDP & LLS (2008) & \\
\hline MCAP & Ratio of market capitalization to GDP & LLS (2008) & \\
\hline SPREAD & Interest rate spread & LLS (2008) & \\
\hline$P R$ & $\begin{array}{l}\text { Property Right } \\
\text { Days to enforce a debt contract in }\end{array}$ & LLSV (1997) & \\
\hline$E D F$ & the legal system & $\begin{array}{l}\text { Djankov et al. } \\
(2007)\end{array}$ & \\
\hline
\end{tabular}


Table 1 presents descriptions and sources of all variables used in the empirical analysis. We collect the macroeconomic control data from the International Monetary Fund (IMF) and country regulation variables from Raphael La Porta's website. ${ }^{5}$ Table I also summarizes the bank control and characteristic variables and the dependent variable (LLP). These data are collected from the BankScope database.

\section{B. Hypotheses and Empirical Specification}

B1. Hypothesis I: Prudential regimes and LLP

We hypothesize that the three commonly cited LLP motivations: income smoothing, capital management and earning signaling will be systematically different for procyclical and dynamic provisioning prudential regimes, after controlling for bank and country-specific factors. We use the commonly cited empirical specification as provided by Whalen (1994) and used by other studies (Ahmed et al., 1999; and Das and Ghosh, 2007). Equation (1) is the baseline equation used to test if LLP are a source of bank earnings management.

$$
\begin{aligned}
L L P_{i, t}= & \gamma_{0}+\gamma_{1} L L P_{i,(t-1)}+\gamma_{2} \operatorname{CRAR}_{i,(t-1)}+\gamma_{3} \operatorname{EBTP}_{i, t} \\
& +\gamma_{4} \Delta \text { EBTP }_{i,(t-1)}+\gamma_{5} \text { Bank Controls }_{i,(t-1)} \\
& +\gamma_{6} \text { Country Controls }_{i,(t-1)}+\varepsilon_{i t}
\end{aligned}
$$

Where, loan loss provision $\left(L L P_{\mathrm{i}, \mathrm{t}}\right)$ is standardized by the previous year's total assets, required Tier-I capital $\left(C R A R_{\mathrm{i},(\mathrm{t}-1)}\right)$ is normalized by risk-weighted asset, earnings before tax and provisions $\left(E B T P_{\mathrm{i}, \mathrm{t}}\right)$ is normalized by the previous year's total assets, and $\triangle E B T P_{\mathrm{i},(\mathrm{t}-1)}$ is the percentage change in EBTP from the previous year.

Due to the nature of prudential regulation which requires bank managers to classify delinquent loans into different categories and set aside provisions based on a default risk matrix before they can write-off the loss, LLP are generally autocorrelated. Accordingly, we include a lag of $L L P_{i, t}$ as an explanatory variable in the regression. Ahmed et al., (1999) suggests that if income smoothing is the primary earnings management objective, the EBTP ${ }_{i, t}$ coefficient will be positive. For capital management to be the principal motivation $C R A R_{i,(t-1)}$ needs to have a negative coefficient. Finally, if the earnings signaling hypothesis is true, $\triangle E B T P_{i,(t-1)}$ will have a positive coefficient. ${ }^{6}$

Hypothesis I states that under different prudential regimes, earnings management motivation(s) should vary; accordingly, we extend the baseline empirical Equation in (1) to account for a regime change, as shown in Equation (2).

\footnotetext{
5 http://faculty.tuck.dartmouth.edu/rafael-laporta/research-publications

6 These hypotheses are not mutually exclusive, one or more of these hypotheses may be simultaneously true.
} 
We consider the pro-cyclical prudential regime as the base case and include a categorical indicator variable for dynamic provisioning $\left(\right.$ DynDum $\left._{i, t}\right)$, where the variable takes a value of 1 if a country follows dynamic provision regulations and is 0 otherwise.

$$
\begin{aligned}
L L P_{i, t}= & \gamma_{0}+\gamma_{1} \text { LLP }_{i,(t-1)}+\gamma_{2} \operatorname{CRAR}_{i,(t-1)}+\gamma_{3} \text { EBTP }_{i, t} \\
& +\gamma_{4} \Delta \text { EBTP }_{i,(t-1)}+\beta_{1} \text { DynDum }_{i, t}+\beta_{2} \text { DynDum }_{i, t} * L L P_{i,(t-1)} \\
& +\beta_{3} \text { DynDum }_{i, t} * \operatorname{CRAR}_{i,(t-1)}+\beta_{4} \text { DynDum }_{i, t} * \text { EBTP }_{i, t} \\
& +\beta_{5} \text { DynDum }_{i, t} * \Delta \text { EBTP }_{i,(t-1)}+\gamma_{5} \text { Bank Controls }_{i,(t-1)} \\
& +\gamma_{6} \text { Country Controls }_{i,(t-1)}+\varepsilon_{i t}
\end{aligned}
$$

B2. Hypothesis II: Accounting standards and LLP

Accounting standards and the $L L P$ literature documents that firms migrating from rules-based to principles-based accounting standards have significant differences in earnings management (Bouvatier et al., 2014; Gebhardt and Novotny-Farkas, 2011). We extend this analysis to a much broader sample of the banking industry and posit that motivations for $L L P$ will be different under these two accounting standards, after controlling for bank and country-specific factors.

Hence, in Hypothesis II, we argue that accounting standards will affect the motivation for managerial discretion of LLP. We use the rules-based accounting standard as the base case and introduce a categorical indicator variable for the principles-based standard (PrincDum $m_{i, t}$ ), where the variable takes a value of 1 if a bank is using principles-based accounting standard and is 0 otherwise. Equation (3) specifies the model:

$$
\begin{aligned}
L L P_{i, t}= & \gamma_{0}+\gamma_{1} L_{L P} P_{i,(t-1)}+\gamma_{2} \operatorname{CRAR}_{i,(t-1)}+\gamma_{3} \operatorname{EBTP}_{i, t}+\gamma_{4} \Delta \operatorname{EBTP}_{i,(t-1)} \\
& +\beta_{1} \operatorname{PrincDum}_{i, t}+\beta_{2} \operatorname{PrincDum}_{i, t} * L L P_{i,(t-1)}+\beta_{3} \operatorname{PrincDum}_{i, t} \\
& * \text { CRAR }_{i,(t-1)}+\beta_{4} \operatorname{PrincDum}_{i, t} * \operatorname{EBTP}_{i, t} \beta_{5} \operatorname{PrincDum}_{i, t} * \Delta E B T P_{i,(t-1)} \\
& +\gamma_{5} \text { Bank Controls }_{i,(t-1)}+\gamma_{6} \text { Country Controls }_{i,(t-1)}+\varepsilon_{i t}
\end{aligned}
$$


B3. Hypothesis III: Combined Effect of changes in Prudential Regimes and changes in Accounting Standards on LLP

A subset of these countries that have transitioned from pro-cyclical to dynamic provisioning regimes are also migrating from local GAAP towards an IFRS standard. ${ }^{7}$

Hypothesis III states that changes in prudential regulations and accounting standards can impart systematically different rationale for managers to pursue earnings management of $L L P$. To investigate this combined impact, we use a specification that combines the indicator variables from Equations (2) and (3). It follows that Equation (4) provides the empirical model:

$$
\begin{aligned}
& L L P_{i, t}=\gamma_{0}+\gamma_{1} L L P_{i,(t-1)}+\gamma_{2} C R A R_{i,(t-1)}+\gamma_{3} E B T P_{i, t}+\gamma_{4} \Delta E B T P_{i,(t-1)} \\
& +\alpha_{1} \text { DynDum }_{i, t}+\beta_{1} \text { PrincDum }_{i, t}+\beta_{2} \text { DynDum }_{i, t} * \operatorname{PrincDum}_{i, t} * L L P_{i,(t-1)} \\
& +\beta_{3} \text { DynDum }_{i, t} * \operatorname{PrincDum}_{i, t} * \operatorname{CRAR}_{i,(t-1)}+\beta_{4} \text { DynDum }_{i, t} * \operatorname{PrincDum}_{i, t} \\
& * E_{B T P} P_{i, t}+\beta_{5} \text { DynDum }_{i, t} * \operatorname{PrincDum}_{i, t} * \Delta E B T P_{i,(t-1)} \\
& +\gamma_{5} \text { Bank Controls }_{i,(t-1)}+\gamma_{6} \text { Country Controls }_{i,(t-1)}+\varepsilon_{i t}
\end{aligned}
$$

\section{Econometric Techniques}

We implement five different econometric approaches in our analysis of LLP and differential motivations encompassed in Equations (1), (2), (3), and (4). Utilizing our large panel dataset, we report regression estimates using pooled ordinary least squares (OLS), least squares dummy variable (LSDV) with year fixed effects (YFE), LSDV with bank fixed effects (BFE), panel estimates with random effects (RE), and panel general method of moments (GMM) estimates using two-step generalized least square (GLS) estimates with White-corrected standard errors. We use several econometric techniques to find more robust evidence on earning management motivation, as it applies to prudential regulations and accounting standards. As the sample includes a large cross-section of banks with fewer time series, we consider pooled OLS to begin with; the Hausman tests suggest that this intuition is correct. ${ }^{8}$ We also use the Arellano and Bond (1991) suggested panel GMM approach with two-step GLS estimations for robustness.

\footnotetext{
7 These countries are Bolivia, Chile, Colombia, India, the Republic of Korea, Paraguay, Peru, Spain, Uruguay, and Venezuela.

8 Hausman (1978).
} 


\section{DESCRIPTIVE STATISTICS}

\section{A. Data and Sample Composition}

Table 2 presents the composition of our sample of banks. It includes 12 years of financial information between 1999 and 2010 for 7,343 banks across 118 countries. BankScope identifies four major accounting standards used in the global banking industry: US GAAP/local GAAP regulatory standards, IAS, and IFRS. US/local GAAP and regulatory standards are classified as rules-based accounting, while IAS and IFRS are classified as principles-based accounting.

\section{Table 2.}

\section{Composition of Sampled Banks}

This table provides the overall bank sample composition, which comprises 12 years of data, from 1999 to 2010, for 7,343 banks in 118 countries. BankScope reports four major types of accounting standards used in the banking industry: US/local GAAP, Regulatory Standards, International Accounting Standards (IAS), and International Financial Reporting Standards (IFRS). These are classified into two major categories: rules-based and principles-based. US/local GAAP and Regulatory Standards are classified as rules-based, and IAS and IFRS are classified as principles-based accounting standards. Furthermore, prudential regulation is broadly categorized into two different types of regimes: pro-cyclical and dynamic. Panel A summarizes the distribution of banks in our sample by both accounting standard and prudential regulatory regime. This distribution is also sub-divided into US and non-US pro-cyclical regimes under the two different accounting standards. Panel B summarizes the accounting practices across the countries under a dynamic provisioning prudential framework. Panel $\mathrm{C}$ displays the frequency of the most current accounting practices for banks in each country where a pro-cyclical regime is the precedent.

\begin{tabular}{lcccccc}
\hline \multicolumn{5}{c}{ Panel A: Distribution of Banks by Prudential Regime and Accounting Standards } \\
\hline & \multicolumn{2}{c}{ Rules-based } & Principles-based & Total & Total \\
\hline Prudential Regime & $\begin{array}{c}\text { Local } \\
\text { GAAP }\end{array}$ & Regulatory & IFRS & IAS & $\begin{array}{c}\text { Rules- } \\
\text { based }\end{array}$ & $\begin{array}{c}\text { Principles- } \\
\text { based }\end{array}$ \\
\hline a) US Pro-cyclical & 235 & 5,703 & - & - & 5,938 & - \\
b) Non-US Pro-cyclical & 874 & - & 270 & 55 & 874 & 325 \\
a) Pro-cyclical & 1,109 & 5,703 & 270 & 55 & 6,812 & 325 \\
b) Dynamic & 108 & 5 & 93 & - & 113 & 93 \\
& 1,217 & 5,708 & 363 & 55 & 6,925 & 418 \\
\hline
\end{tabular}

Panel B: Accounting Practices Under Dynamic Provisioning Prudential Regime

\begin{tabular}{llcccc}
\hline & \multicolumn{2}{c}{ Rules-based } & \multicolumn{2}{c}{ Principles-based } \\
\hline Country & $\begin{array}{c}\text { Local } \\
\text { GAAP }\end{array}$ & $\begin{array}{c}\text { Regulatory } \\
\text { standards }\end{array}$ & IFRS & IAS \\
\hline 1 & Bolivia & 8 & - & - & - \\
2 & Chile & 1 & - & - & - \\
3 & Colombia & 10 & - & - & - \\
4 & India & 46 & - & - & - \\
5 & Italy & - & - & 68 & - \\
6 & Korea, Rep. of & 6 & - & - & - \\
7 & Paraguay & 10 & - & - & - \\
8 & Peru & 5 & 5 & - & - \\
9 & Spain & - & - & 23 & - \\
10 & Uruguay & 9 & - & 2 & - \\
11 & Venezuela & 13 & - & - & - \\
& Total & 108 & 5 & 93 & - \\
\hline
\end{tabular}


Table 2.

Composition of Sampled Banks (Continued)

\begin{tabular}{|c|c|c|c|c|c|c|c|c|c|c|c|}
\hline \multicolumn{12}{|c|}{ Panel C: Accounting Practices Under Pro-cyclical Prudential Regime } \\
\hline & & \multicolumn{2}{|c|}{ Rules-based } & \multicolumn{2}{|c|}{$\begin{array}{c}\text { Principles- } \\
\text { based }\end{array}$} & & & \multicolumn{2}{|c|}{ Rules-based } & \multicolumn{2}{|c|}{$\begin{array}{c}\text { Principles- } \\
\text { based }\end{array}$} \\
\hline \multicolumn{2}{|c|}{ Country } & $\begin{array}{l}\text { Local } \\
\text { GAAP }\end{array}$ & $\begin{array}{l}\text { Reg. } \\
\text { Std. }\end{array}$ & IFRS & IAS & Cou & untry & $\begin{array}{l}\text { Local } \\
\text { GAAP }\end{array}$ & $\begin{array}{l}\text { Reg. } \\
\text { Std. }\end{array}$ & IFRS & IAS \\
\hline 1 & Albania & - & - & 2 & - & 27 & Costa-Rica & 13 & - & - & - \\
\hline 2 & Algeria & 4 & - & - & - & 28 & Croatia & - & - & 17 & - \\
\hline 3 & Angola & 1 & - & - & - & 29 & Cyprus & 1 & - & 3 & - \\
\hline 4 & Argentina & 22 & - & - & - & 30 & Czech Rep. & 4 & - & 6 & - \\
\hline 5 & Armenia & - & - & 1 & 2 & 31 & Denmark & 25 & - & - & - \\
\hline 6 & Austria & 25 & - & 4 & - & 32 & Dominican Rep. & 12 & - & - & - \\
\hline 7 & Azerbaijan & - & - & 5 & - & 33 & Ecuador & 16 & - & - & - \\
\hline 8 & Bahamas & - & - & 3 & 2 & 34 & Egypt & 16 & - & - & 4 \\
\hline 9 & Bahrain & - & - & 8 & - & 35 & El Salvador & 5 & - & - & - \\
\hline 10 & Bangladesh & 18 & - & - & - & 36 & Estonia & - & - & 3 & - \\
\hline 11 & Barbados & - & - & 1 & - & 37 & Ethiopia & 1 & - & 1 & 1 \\
\hline 12 & Belarus & - & - & 4 & - & 38 & France & 53 & - & - & - \\
\hline 13 & Belgium & 12 & - & - & - & 39 & Georgia Rep. & - & - & 5 & - \\
\hline 14 & Benin & 2 & - & - & - & 40 & Germany & 69 & - & 5 & - \\
\hline 15 & Bhutan & 2 & - & - & - & 41 & Guatemala & 12 & - & - & - \\
\hline 16 & Bosnia & 1 & - & 5 & - & 42 & Guyana & - & - & 1 & 1 \\
\hline 17 & Botswana & - & - & 1 & 1 & 43 & Honduras & 10 & - & - & - \\
\hline 18 & Brazil & 44 & - & - & - & 44 & Hungary & 5 & - & 5 & - \\
\hline 19 & Brunei & 1 & - & - & - & 45 & Indonesia & 27 & - & - & - \\
\hline 20 & Bulgaria & - & - & 9 & - & 46 & Iran & 4 & - & - & - \\
\hline 21 & Burkina-Faso & 3 & - & - & - & 47 & Israel & 10 & - & - & - \\
\hline 22 & Burundi & 1 & - & - & - & 48 & Japan & 110 & - & - & - \\
\hline 23 & Cambodia & - & - & - & 1 & 49 & Jordan & 1 & - & 10 & 1 \\
\hline 24 & Cameroon & 2 & - & - & - & 50 & Kazakhstan & - & - & 9 & - \\
\hline 25 & Canada & 27 & - & - & - & 51 & Kenya & - & - & 8 & 4 \\
\hline 26 & China & 12 & - & 1 & 1 & 52 & Kuwait & - & - & 5 & - \\
\hline 27 & Costa-Rica & 13 & - & - & - & 53 & Kyrgyzstan & - & - & - & 1 \\
\hline
\end{tabular}


Table 2.

Composition of Sampled Banks (Continued)

\begin{tabular}{|c|c|c|c|c|c|c|c|c|c|c|c|}
\hline & & Rules- & based & $\begin{array}{r}\text { Princi } \\
\text { bas }\end{array}$ & $\begin{array}{l}\text { ples- } \\
\text { ed }\end{array}$ & & & Rules- & based & $\begin{array}{r}\text { Princ } \\
\text { bas }\end{array}$ & $\begin{array}{l}\text { ples- } \\
\text { ed }\end{array}$ \\
\hline & untry & $\begin{array}{l}\text { Local } \\
\text { GAAP }\end{array}$ & $\begin{array}{l}\text { Reg. } \\
\text { Std. }\end{array}$ & IFRS & IAS & Cou & untry & $\begin{array}{l}\text { Local } \\
\text { GAAP }\end{array}$ & $\begin{array}{l}\text { Reg. } \\
\text { Std. }\end{array}$ & IFRS & IAS \\
\hline 54 & Latvia & - & - & 6 & - & 81 & Rwanda & - & - & - & 2 \\
\hline 55 & Lebanon & 1 & - & 8 & 8 & 82 & Saudi Arabia & 1 & - & 9 & - \\
\hline 56 & Lithuania & 0 & - & 6 & - & 83 & Senegal & 2 & - & - & - \\
\hline 57 & Luxembourg & 35 & - & - & - & 84 & Serbia & 1 & - & 3 & - \\
\hline 58 & Malawi & 0 & - & - & 3 & 85 & Sierra Leone & - & - & - & 3 \\
\hline 59 & Malaysia & 25 & - & - & - & $86 \leqq$ & Slovakia & - & - & 8 & - \\
\hline 60 & Mali & 3 & - & - & - & 87 & Slovenia & - & - & 10 & - \\
\hline 61 & Malta & - & - & 2 & - & 88 & South Africa & 1 & - & - & - \\
\hline 62 & Mauritius & - & - & 2 & 1 & 89 & Sri Lanka & 9 & - & - & - \\
\hline 63 & Mexico & 22 & - & - & - & & & - & - & - & 2 \\
\hline 64 & Moldova Rep. & - & - & 1 & 1 & & & 5 & - & - & - \\
\hline 65 & Mongolia & - & - & 1 & - & & & 2 & - & - & - \\
\hline 66 & Morocco & 2 & - & - & - & & & & & & \\
\hline 67 & Mozambique & - & - & 2 & - & & & & & & \\
\hline 68 & Nepal & 8 & - & - & - & & & & & & \\
\hline 69 & Netherlands & 3 & - & - & - & & & & & & \\
\hline 70 & Nicaragua & 2 & - & - & - & & & & & & \\
\hline 71 & Niger & 2 & - & - & - & & & & & & \\
\hline 72 & Nigeria & 6 & - & - & - & & & & & & \\
\hline 73 & Norway & 2 & - & - & - & & & & & & \\
\hline 74 & Oman & - & - & 5 & - & & & & & & \\
\hline 75 & Pakistan & 5 & - & - & - & & & & & & \\
\hline 76 & Panama & 2 & - & 7 & - & & & & & & \\
\hline 77 & Poland & 4 & - & - & - & & & & & & \\
\hline 78 & Qatar & 1 & - & 5 & - & & & & & & \\
\hline 79 & Romania & - & - & 8 & - & & & & & & \\
\hline 80 & Russian Fed. & 4 & - & 21 & - & & & & & & \\
\hline
\end{tabular}


Panel A summarizes the distribution of banks by accounting standard and prudential regulatory regime. This panel is further sub-divided into US and nonUS pro-cyclical regimes under the two different accounting standards analyzed. Of the 7,343 commercial banks, 6,925 banks use rules-based standard, while 1,217 banks comply with local GAAP rules and the remaining 5,708 banks comply with mandatory regulatory standards. Alternatively, only 418 banks fall under the principles-based accounting standard, with 363 banks complying with the IFRS and the remaining 55 with the IAS regulations. Of the 6,925 banks complying with the rules-based norms, the vast majority (6,812 banks) adhere to a pro-cyclical provisioning regime, while the remaining 113 banks fall under the purview of a dynamic regime. Similarly, of the 418 banks under a principles-based accounting standard, 325 banks fall under a pro-cyclical regime, while the other 93 are associated with dynamic provisioning. Analyzing the overall sample, 5,938 banks (a significant portion) in the dataset constitute US financial institutions and fall under a rules-based and pro-cyclical regime. Further, there is little diversity among the US banks in that 5,703 banks comply with regulatory standards set forth by financial regulators, while the remaining 235 institutions comply with the US/ local GAAP. The remaining sample of pro-cyclical banks $(1,109)$ are international banks, and of these 874 conform to the rules-based standards, while the remaining 325 falls under the category of principles-based.

Panel B summarizes accounting practices across countries following the dynamic provisioning rules. Presently, regulators in 11 countries (Bolivia, Chile, Colombia, India, Italy, South Korea, Paraguay, Peru, Spain, Uruguay, and Venezuela) pursue a dynamic prudential regulatory regime. While these countries share the same prudential framework, the shift in regulatory regime for each nation from a pro-cyclical to a dynamic provisioning regime occurred over different time periods. Spain, one of the pioneer countries to initiate dynamic provisioning, initiated the change in 2001. Later, Uruguay adopted such rules at the beginning of 2007. Despite this heterogeneity in the regime adoption policy, the frequency distribution depicts the most current information on accounting practices for banks that have changed or are currently changing prudential regimes. Panel C displays the most current accounting practices for banks in nations where the procyclical regime is a precedent. This portion of the overall sample is made up of a total of 107 countries.

\section{B. Descriptive Statistics of Bank Variables}

Table 3 presents summary statistics for bank financial characteristics for the overall sample (1999 to 2010) period. Panel A presents summary statistics for all banks, of $L L P, E B T P, C R A R$, total regulatory capital (TRG) - which represents the equity that must be held by financial institutions as a legal requirement set by regulators as a percentage of RWA, return on average assets (ROAA), return on average equity (ROAE), and bank total assets (TA). LLP, EBTP, CRAR, TRG, ROAA, and ROAE are measured as percentages; TA is measured in thousands of US dollars. The mean value of bank TA are $\$ 4.63$ billion, while the median size is only $\$ 141.6$ million. The large standard deviation of bank TA ( $\$ 52.7$ billion) reveals severe variation among the different institutions in terms of their dollar asset size; 
this large disparity is driven by US banks. Similarly, the distribution of LLP also has high variability about its mean.

Table 3.

\section{Bank Descriptive Statistics}

This table reports the descriptive statistics for the overall sample of banks, which comprises 12 years of data, from 1999 to 2010, for 7,343 banks in 118 countries. Panel A presents the summary statistics, for all banks, of loan loss provisions (LLP), earnings before tax and provisions $(E B T P)$, Tier-I required capital (CRAR), total regulatory capital (TRG), return on average assets $(R O A A)$, return on average equity (ROAE), and bank total assets (TA). LLP and EBTP are normalized by total assets (which is measured in thousands of dollars), while CRAR and TRG are both normalized with respect to risk-weighted assets (RWA). LLP, EBTP, CRAR, $T R G, R O A A$, and ROAE are measured as percentages. Panel B reports similar summary statistics for banks under either the procyclical loan loss provisioning regime or the dynamic provisioning regime. Panel $C$ summarizes the descriptive statistics of the banks classified by the two broad accounting standards: rules-based and principles-based. Welch $t$-statistics are reported for the difference in mean between competing regimes and accounting standards, where ${ }^{* * *}$, and ${ }^{* * *}$ denote $1 \%, 5 \%$, and $10 \%$ levels of significance based on two-tailed test statistics, respectively.

\begin{tabular}{|c|c|c|c|c|c|c|c|c|c|}
\hline \multicolumn{10}{|c|}{ Panel A: Overall Sample } \\
\hline & & \multicolumn{3}{|c|}{ Mean } & \multicolumn{2}{|l|}{ Median } & \multicolumn{2}{|l|}{$\begin{array}{l}\text { Std. } \\
\text { Dev. }\end{array}$} & $\begin{array}{l}\text { Bank } \\
\text { Years }\end{array}$ \\
\hline$L L P$ & & \multicolumn{3}{|c|}{40.79} & \multicolumn{2}{|l|}{17.11} & \multicolumn{2}{|l|}{101.96} & 85,870 \\
\hline EBTP & & \multicolumn{3}{|c|}{17.66} & 13.6 & & \multicolumn{2}{|l|}{24.56} & 77,961 \\
\hline CRAR & & \multicolumn{3}{|c|}{18.96} & 14.8 & & \multicolumn{2}{|l|}{24.14} & 79,762 \\
\hline TRG & & \multicolumn{3}{|c|}{1.76} & 1.5 & & \multicolumn{2}{|l|}{4.51} & 86,758 \\
\hline$R O A A$ & & \multicolumn{3}{|c|}{1.05} & 1.01 & & \multicolumn{2}{|l|}{2.64} & 87,296 \\
\hline$R O A E$ & & \multicolumn{3}{|c|}{9.61} & 9.83 & & \multicolumn{2}{|l|}{17.44} & 87,286 \\
\hline $\mathrm{TA}$ & & \multicolumn{3}{|c|}{$4,625,954$} & 141,568 & & \multicolumn{2}{|c|}{$52,748,755$} & 87,329 \\
\hline \multicolumn{10}{|c|}{ Panel B: Banks Under Pro-cyclical Regime vs. Banks Under Dynamic Provisioning Regime } \\
\hline & \multicolumn{4}{|c|}{ Pro-cyclical } & \multicolumn{4}{|c|}{ Dynamic } & Welch \\
\hline & Mean & Median & $\begin{array}{l}\text { Std. } \\
\text { Dev. }\end{array}$ & Obs. & Mean & Median & $\begin{array}{l}\text { Std. } \\
\text { Dev. }\end{array}$ & Obs. & $t$-statistic \\
\hline LLP & 39.96 & 16.74 & 101.42 & 84,143 & 81.46 & 48.63 & 118.78 & 1,727 & $-14.41^{* * *}$ \\
\hline EBTP & 17.74 & 13.6 & 24.63 & 76,962 & 12.09 & 8.85 & 17.17 & 999 & $10.25^{* * *}$ \\
\hline CRAR & 19.01 & 14.88 & 24.23 & 78,607 & 15.09 & 12.34 & 16 & 1,155 & $8.21^{* * *}$ \\
\hline$T R G$ & 1.75 & 1.5 & 4.32 & 85,066 & 2.2 & 2.01 & 10.26 & 1,692 & $-1.82^{* *}$ \\
\hline$R O A A$ & 1.05 & 1.01 & 2.64 & 85,477 & 1.13 & 0.9 & 2.68 & 1,819 & -1.35 \\
\hline$R O A E$ & 9.57 & 9.81 & 17.04 & 85,467 & 11.6 & 12.11 & 30.8 & 1,819 & $-2.80^{* * *}$ \\
\hline$T A$ & $4,164,919$ & 136,951 & $49,836,865$ & 85,509 & $26,286,730$ & $2,831,166$ & $128,000,000$ & 1,820 & $-7.36^{* * *}$ \\
\hline \multicolumn{10}{|c|}{$\begin{array}{l}\text { Panel C: Banks using rules-based accounting standard vs. banks using principles-based } \\
\text { accounting standard }\end{array}$} \\
\hline & \multicolumn{4}{|c|}{ Rules-based } & \multicolumn{4}{|c|}{$\begin{array}{l}\text { Principles-based } \\
\end{array}$} & Welch \\
\hline & Mean & Median & $\begin{array}{l}\text { Std. } \\
\text { Dev. }\end{array}$ & Obs. & Mean & Median & $\begin{array}{l}\text { Std. } \\
\text { Dev. }\end{array}$ & Obs. & $t$-statistic \\
\hline$L L P$ & 37.97 & 16.41 & 91.98 & 81,638 & 95.32 & 44.89 & 211.27 & 4,232 & $-17.58^{* * *}$ \\
\hline EBTP & 17.69 & 13.6 & 24.82 & 75,473 & 16.82 & 13.71 & 14.74 & 2,488 & $2.81^{* * *}$ \\
\hline CRAR & 18.92 & 14.71 & 24.46 & 76,538 & 19.77 & 16.16 & 14.73 & 3,224 & $-3.11^{* * *}$ \\
\hline$T R G$ & 1.7 & 1.5 & 4.56 & 82,483 & 2.83 & 2.26 & 3.24 & 4,275 & $-21.82^{* * *}$ \\
\hline$R O A A$ & 1.03 & 1 & 2.54 & 82,839 & 1.5 & 1.27 & 4.03 & 4,457 & $-7.74^{* * *}$ \\
\hline$R O A E$ & 9.51 & 9.76 & 15.64 & 82,835 & 11.52 & 12.09 & 37.55 & 4,451 & $-3.55^{* * *}$ \\
\hline$T A$ & $3,772,834$ & 133,023 & $46,303,099$ & 82,865 & $20,462,381$ & $1,122,938$ & $120,000,000$ & 4,464 & $-9.26^{* * *}$ \\
\hline
\end{tabular}


Panel B presents summary statistics for banks under competing pro-cyclical and dynamic provisioning regimes. It is clear that banks under the dynamic regime generally set aside higher $L L P$ compared to their pro-cyclical counterparts. Bank managers maintain EBTP of an average of $39.96 \%$ of TA for $L L P$ under a procyclical regime, while managers under dynamic provisioning retain an average of $81.46 \%$ of TA for LLP. This difference complements the fact that bank EBTP in pro-cyclical regimes are generally higher than that of banks under a dynamic provisioning regime. Regarding capital adequacy, we find that banks in procyclical regimes maintain higher Tier-I capital requirements. These findings imply that banks may use $L L P$ in managing capital adequacy requirements.

Panel $C$ presents summary statistics of banks classified by accounting standards. We find that bank managers using principles-based norms maintain higher LLPthat is, an average of $95.32 \%$ of TA, while managers following rules-based norms only retain an average of $37.97 \%$ of TA as $L L P$. In addition, capital requirements and profitability ratios are generally higher for banks following the principlesbased accounting standards, and these differences are statistically significant at conventional levels. Overall, there appear to be significant differences in bank characteristics based on prudential regulation regime and accounting standards.

\section{Country Control Variables}

Table 4 presents summary statistics of the country control variables that include both country-specific macroeconomic factors (Panel A) and regulatory/legal factors (Panel B). Macroeconomic variables include per capita GDP (PCGDP), per capita GDP growth (PCGDPG), and inflation (INFL). Following LLS (2008), we include several regulatory/legal control variables, namely the accounting disclosure index (DISCL), efficiency of debt enforcement (EDF), property rights (PR), market capitalization (MCAP), privatization (PRIVO), and interest rate spread (SPRD). ${ }^{9}$

From Panel A, we note that average PCGDP for the overall sample of countries increases steadily from about 2001 to 2008. However, post-2008, it declines moderately $(7.15 \%)$ which coincides with the GFC. Average inflation exhibits a gradual decrease from 1999 to 2007 before increasing sharply over the 2008 period and then precipitously falling below $5 \%$ post-crisis. While countryspecific macroeconomic variables are time variant, regulatory control variables are generally constant for the given set of countries. Panel B highlights the regulatory and legal control variable summary statistics. The interpretations of the variables follow that of LLS (2008) and Djankov, McLiesh, and Schleifer (2007).

9 Variable definitions follow in Table I and are defined following LLS (2008) and LLSV (1997). 


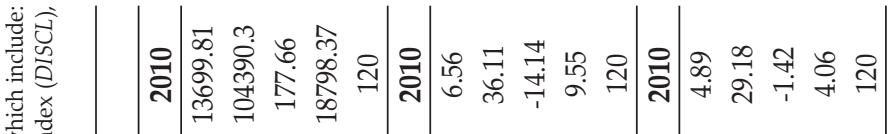

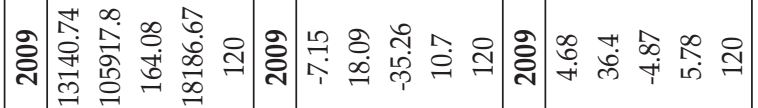

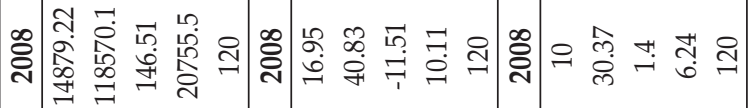

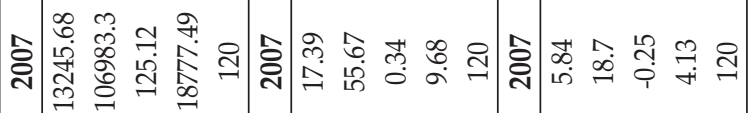

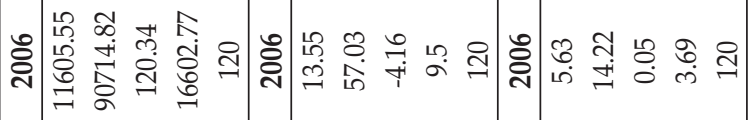

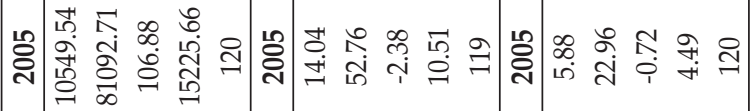

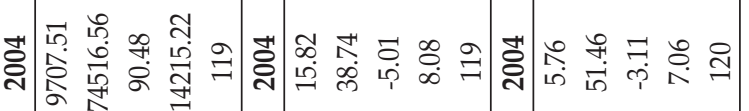

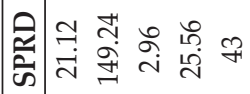

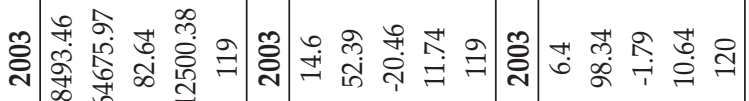

结乎

च

ธิ)

西

일

感

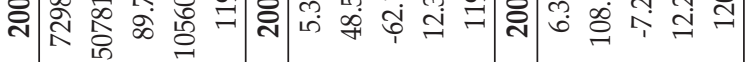

矛管

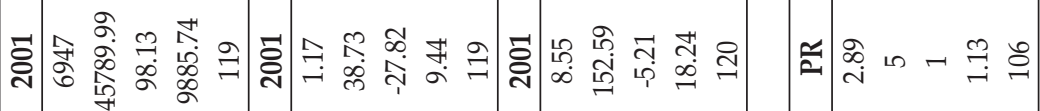

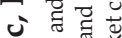

音

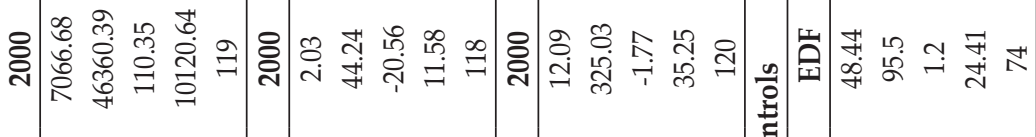

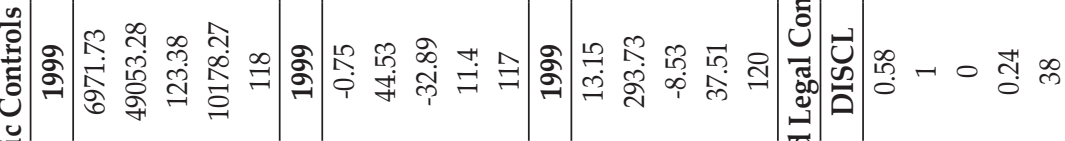

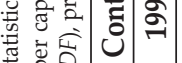

悹

를

宅

की

se

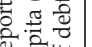

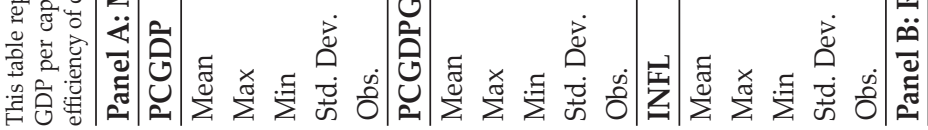




\section{REGRESSION RESULTS}

\section{A. Evidence on Loan Loss Provisioning: Overall Sample}

First, we investigate the presence and motivation of earnings management via LLP using the overall sample of 118 countries (a total 57,967 bank years) without differentiating between accounting standards and prudential regulatory regimes. The income smoothing hypothesis contends that a positive relation exists between LLP and EBTP, implying that banks keep higher LLP during business cycle expansions. The capital management hypothesis argues $L L P$ is negatively related with $C R A R$, as bank managers use $L L P$ reserves as part of the regulatory capital requirements when shortfalls occur. Lastly, the earnings signaling hypothesis suggests that $L L P$ is positively related to $\triangle E B T P$, as managers use $L L P$ as a signal to convey better financial health of the bank to the investors.

Table 5 presents the regression estimates for the baseline Equation (1). First, we note that LLP is positively related to its one-period lag, consistent with the pro-cyclicality paradigm. This observation seems rather obvious as only 11 of the 118 countries in the sample pursue dynamic provisioning regimes, while the other countries generally follow the pro-cyclicality rules. Second, we note that, in general, $L L P$ is negatively related to CRAR providing evidence that banks use $L L P$ as tool to help manage their Tier-I capital requirements. Third, LLP is positively related to EBTP, supporting the income smoothing hypothesis. Lastly, we find no evidence in favor of the earnings signaling argument as $\triangle E B T P$ is insignificant in all regression estimates. Parameter estimates and significance are robust to regression estimators and model specification.

Table 5.

\section{LLP Overall Panel Regression}

This table reports panel regression results following the model as specified in equation (1). The sample period spans from 19992010 with 7,343 banks and a total of 57,967 bank years, in 118 countries. Column (1) presents the regression estimates using pooled ordinary least squares (OLS). Column (2) reports regression estimates using least squares dummy variable (LSDV) with year fixed effects (YFE). Column (3) presents regression estimates using LSDV with bank fixed effects (BFE). Column (4) reports regression panel estimates with random effects (RE). Column (5) reports the panel general method of moments (GMM) estimates using twostep generalized least square (GLS) estimates with White-corrected standard errors. For each variable, the first row corresponds to the coefficient estimate and the second row reports the standard error in parenthesis. Based on two-tailed test statistics, ${ }^{* * *},{ }^{* *}$, and * denote $1 \%, 5 \%$, and $10 \%$ levels of significance, respectively. Loan loss provisions $(L L P)$ is the dependent variable. Explanatory variables include the one-period lag of loan loss provision $\left(L L P_{i,(t-1)}\right)$, Tier-I required capital $\left(C R A R_{i,(t-1)}\right)$, earnings before tax and provisions $\left(E B T P_{i}\right)$, change in earnings before tax and provisions $\left(\triangle E B T P_{i, t-1)}\right)$, natural log of total assets $(L N T A)$ as control for bank size, several country control variables: GDP per capita (PCGDP), GDP per capita growth (PCGDPG), inflation (INFL), and several regulatory/legal variables: accounting disclosure index (DISCL), efficiency of debt enforcement (EDF), property rights (PR), market capitalization (MCAP), privatization (PRIVO), and interest rate spread (SPRD). Both $L L P_{i, t}$ and $E B T P_{i, t}$ are normalized by the oneperiod lag of $T A$, and $C R A R_{i,(t-1)}$ is normalized by risk-weighted assets (RWA). PCGDP and PCGDPG are measured in US Dollars.

\begin{tabular}{|c|c|c|c|c|c|c|c|c|c|c|c|}
\hline & & (1) & & $(2)$ & & (3) & & (4) & & (5) & \\
\hline & & OLS & & YFE & & BFE & & RE & & GMM & \\
\hline \multirow[t]{2}{*}{ CONS } & & 64.790 & *** & -29.902 & *** & 64.790 & $* * *$ & 1.166 & $* * *$ & -- & \\
\hline & & [8.990] & & [10.110] & & [8.730] & & {$[0.000]$} & & -- & \\
\hline \multicolumn{12}{|c|}{ a. Bank Characteristics } \\
\hline \multirow[t]{2}{*}{$L L P i,(t-1)$} & $(+)$ & 0.510 & $* * *$ & 0.498 & $* * *$ & 0.510 & $* * *$ & 0.000 & $* * *$ & 0.506 & $* * *$ \\
\hline & & {$[0.005]$} & & {$[0.005]$} & & {$[0.004]$} & & {$[0.000]$} & & {$[0.005]$} & \\
\hline \multirow[t]{2}{*}{ CRARi, $(t-1)$} & $(-)$ & -0.091 & $* * *$ & -0.093 & $* * *$ & -0.091 & $* * *$ & 0.001 & $* * *$ & -0.089 & $* * *$ \\
\hline & & {$[0.011]$} & & {$[0.011]$} & & {$[0.010]$} & & {$[0.000]$} & & {$[0.011]$} & \\
\hline \multirow[t]{2}{*}{ EBTPi,t } & $(+)$ & 0.556 & $* * *$ & 0.59 & $* * *$ & 0.556 & $* * *$ & 0.006 & $* * *$ & 0.537 & $* * *$ \\
\hline & & {$[0.068]$} & & {$[0.067]$} & & {$[0.066]$} & & {$[0.000]$} & & {$[0.068]$} & \\
\hline
\end{tabular}


Table 5.

LLP Overall Panel Regression (Continued)

\begin{tabular}{|c|c|c|c|c|c|c|c|c|c|c|}
\hline & (1) & & (2) & & (3) & & (4) & & (5) & \\
\hline & OLS & & YFE & & BFE & & RE & & GMM & \\
\hline \multirow[t]{2}{*}{$\triangle E B T P i,(t-1) \quad(+)$} & -0.009 & & 0.062 & & -0.009 & & 0.002 & $* * *$ & 0.004 & \\
\hline & {$[0.137]$} & & {$[0.135]$} & & {$[0.133]$} & & {$[0.000]$} & & [0.137] & \\
\hline \multicolumn{11}{|l|}{ b. Bank Control } \\
\hline \multirow[t]{2}{*}{ LNTA } & 3.635 & $* * *$ & 3.583 & $* * *$ & 3.635 & $* * *$ & 1.166 & ** & 3.683 & **** \\
\hline & {$[0.191]$} & & [0.189] & & {$[0.186]$} & & {$[0.000]$} & & [0.192] & \\
\hline \multicolumn{11}{|c|}{ c. Country Macroeconomic Controls } \\
\hline \multirow[t]{2}{*}{ PCGDP } & 0.001 & $* * *$ & 0.000 & $* * *$ & 0.001 & $* * *$ & 0.000 & ** & 0.001 & *** \\
\hline & {$[0.000]$} & & {$[0.000]$} & & {$[0.000]$} & & {$[0.000]$} & & {$[0.000]$} & \\
\hline \multirow[t]{2}{*}{ PCGDPG } & -3.294 & $* * *$ & 0.349 & $* * *$ & -3.294 & $* * *$ & 0.001 & ** & -3.581 & $* * *$ \\
\hline & [0.098] & & [0.149] & & [0.095] & & {$[0.213]$} & & [0.102] & \\
\hline \multirow[t]{2}{*}{ INFL } & -1.376 & $* * *$ & -0.724 & $* * *$ & -1.376 & $* * *$ & 0.011 & $* *$ & -1.160 & $* * *$ \\
\hline & [0.201] & & [0.318] & & [0.195] & & {$[0.000]$} & & {$[0.210]$} & \\
\hline \multirow[t]{2}{*}{ PRIVO } & -22.513 & $* * *$ & 5.193 & & -22.513 & $* * *$ & -- & & -20.694 & $* * *$ \\
\hline & [4.561] & & [5.015] & & [4.429] & & -- & & [5.077] & \\
\hline \multirow[t]{2}{*}{ MCAP } & 34.833 & $* * *$ & 12.11 & * & 34.833 & $* * *$ & -- & & 33.549 & $* * *$ \\
\hline & [7.327] & & [7.389] & & [7.115] & & -- & & [8.313] & \\
\hline \multirow[t]{2}{*}{ SPREAD } & -0.058 & & 0.008 & & -0.058 & & -- & & -0.099 & $* *$ \\
\hline & [0.044] & & [0.046] & & {$[0.043]$} & & -- & & [0.045] & \\
\hline \multirow[t]{2}{*}{$P R$} & -11.727 & $* * *$ & 1.965 & & -11.727 & & -- & & -10.512 & $* * *$ \\
\hline & [1.926] & & [2.574] & & [1.870] & & -- & & [2.098] & \\
\hline \multirow[t]{2}{*}{ DISCL } & 19.693 & * & -9.766 & & 19.693 & & -- & & 19.918 & * \\
\hline & [10.563] & & [11.747] & & [10.258] & & -- & & [11.726] & \\
\hline \multirow[t]{2}{*}{$E D F$} & -1.034 & $* * *$ & -0.210 & $* * *$ & -1.034 & $* * *$ & -- & & -1.092 & $* * *$ \\
\hline & {$[0.061]$} & & {$[0.073]$} & & {$[0.060]$} & & -- & & {$[0.066]$} & \\
\hline Adj. R-sqd. & 0.400 & & 0.413 & & 0.400 & & 0.435 & & 0.402 & \\
\hline
\end{tabular}

B. Impact on Prudential Regulations on LLP

Hypothesis I states that the motivation for earnings management via LLP under different prudential regulation should be dissimilar as each regime promotes different incentives for using earnings management. We consider the commonly followed pro-cyclic provisioning regime as the base case and include an indicator variable for dynamic provisioning as shown in Equation (2). Table 6 summarizes the regression estimates.

Panel B shows that the indicator variable (DynDum) and interaction terms reveal little change in motivation across the panel. Specifically, compared to banks following pro-cyclical rules, banks following dynamic provisioning rules exhibit weak evidence of any systematic change in motive to conduct earnings management using $L L P$. We note that under the dynamic provisioning regime the one-period lag of LLP becomes negative (-0.042), although it is statistically insignificant at conventional levels. Nonetheless, this suggests that the procyclicality is altered under the dynamic regime. Similar to our results from Equation (1), we find strong support for both the income smoothing and capital 
management hypotheses. The negative (positive) coefficients on the CRAR (EBTP) interaction terms show that managers complying with dynamic rules also use LLP as a tool for capital management and income smoothing like banks following procyclical rules. What is particularly interesting is the magnitude of the interaction terms in Panel B; they show that under the dynamic provisioning regime banks pursuing an income smoothing motive will generally set aside a larger amount of $L L P$ than pro-cyclical firms. In contrast, banks pursuing capital management motives will set aside a slightly smaller amount of LLP for that purpose when compared to the pro-cyclical counterpart. We again find no significant empirical evidence for $L L P$ as an earnings signaling tool.

Table 6.

\section{LLP and Prudential Regulatory Regime Regression}

This table reports panel regression results following the model as specified in equation (1). The sample period spans from 19992010 with 7,343 banks and a total of 57,967 bank years, in 118 countries. Column (1) presents the regression estimates using pooled ordinary least squares (OLS). Column (2) reports regression estimates using least squares dummy variable (LSDV) with year fixed effects (YFE). Column (3) presents regression estimates using LSDV with bank fixed effects (BFE). Column (4) reports regression panel estimates with random effects (RE). Column (5) reports the panel general method of moments (GMM) estimates using twostep generalized least square (GLS) estimates with White-corrected standard errors. For each variable, the first row corresponds to the coefficient estimate and the second row reports the standard error in parenthesis. Based on two-tailed test statistics, ${ }^{* * *},{ }^{* *}$, and * denote $1 \%, 5 \%$, and $10 \%$ levels of significance, respectively. Loan loss provisions $(L L P)$ is the dependent variable. Explanatory variables include the one-period lag of loan loss provision $\left(L L P_{i, t(-1-1)}\right)$, Tier-I required capital $\left(C R A R_{i,(t-1)}\right)$, earnings before tax and provisions $\left(E B T P_{i, t}\right)$, change in earnings before tax and provisions $\left(\triangle E B T P_{i,(t-1)}\right)$, natural log of total assets $(L N T A)$ as control for bank size, several country control variables: GDP per capita (PCGDP), GDP per capita growth (PCGDPG), inflation (INFL), and several regulatory/legal variables: accounting disclosure index (DISCL), efficiency of debt enforcement (EDF), property rights (PR), market capitalization (MCAP), privatization (PRIVO), and interest rate spread (SPRD). Both $L L P_{i, t}$ and EBTP $P_{i, t}$ are normalized by the one-period lag of $T A$, and $C R A R_{i,(t-1)}$ is normalized by risk-weighted assets (RWA). PCGDP and PCGDPG are measured in US Dollars. DynDum i, is an indicator variable equal to 1 if the prudential regulatory regime of a country follows dynamic provisioning and 0 otherwise.

\begin{tabular}{|c|c|c|c|c|c|c|c|c|c|c|}
\hline & \multicolumn{2}{|l|}{ (1) } & \multicolumn{2}{|l|}{ (2) } & \multicolumn{2}{|l|}{ (3) } & (4) & \\
\hline & OLS & & YFE & & BFE & & RE & & \multicolumn{2}{|l|}{$\frac{\text { (5) }}{\text { GMM }}$} \\
\hline \multirow[t]{2}{*}{ CONS } & 100.346 & $* * *$ & 7.217 & & 100.346 & $* * *$ & -248.685 & $* * *$ & -- & \\
\hline & [10.110] & & [12.584] & & [9.828] & & [11.658] & & -- & \\
\hline \multicolumn{11}{|l|}{ a. Bank Characteristics } \\
\hline$L L P i,(t-1)$ & $\begin{array}{c}0.508 \\
{[0.005]}\end{array}$ & $* * *$ & $\begin{array}{c}0.498 \\
{[0.005]}\end{array}$ & $* * *$ & $\begin{array}{c}0.508 \\
{[0.004]}\end{array}$ & $* * *$ & $\begin{array}{c}0.333 \\
{[0.005]}\end{array}$ & $* * *$ & $\begin{array}{c}0.505 \\
{[0.005]}\end{array}$ & $* * *$ \\
\hline CRARi, $(t-1)$ & $\begin{array}{c}-0.091 \\
{[0.011]}\end{array}$ & $* * *$ & $\begin{array}{c}-0.093 \\
{[0.011]}\end{array}$ & $* * *$ & $\begin{array}{l}-0.091 \\
{[0.010]}\end{array}$ & $* * *$ & $\begin{array}{c}-0.212 \\
{[0.028]}\end{array}$ & $* * *$ & $\begin{array}{c}-0.089 \\
{[0.011]}\end{array}$ & $* * *$ \\
\hline EBTPi,t & $\begin{array}{c}0.542 \\
{[0.068]}\end{array}$ & $* * *$ & $\begin{array}{c}0.580 \\
{[0.067]}\end{array}$ & $* * *$ & $\begin{array}{c}0.542 \\
{[0.066]}\end{array}$ & $* * *$ & $\begin{array}{c}0.033 \\
{[0.100]}\end{array}$ & & $\begin{array}{c}0.530 \\
{[0.068]}\end{array}$ & *** \\
\hline$\triangle E B T P i,(t-1)$ & $\begin{array}{l}-0.030 \\
{[0.138]}\end{array}$ & & $\begin{array}{c}0.049 \\
{[0.137]}\end{array}$ & & $\begin{array}{l}-0.030 \\
{[0.135]}\end{array}$ & & $\begin{array}{c}0.236 \\
{[0.143]}\end{array}$ & & $\begin{array}{c}-0.021 \\
{[0.138]}\end{array}$ & \\
\hline \multicolumn{11}{|c|}{ b. Impact of Dynamic Provisioning } \\
\hline DynDumi,t & $\begin{array}{l}-47.187 \\
{[6.231]}\end{array}$ & $* * *$ & $\begin{array}{l}-28.628 \\
{[6.612]}\end{array}$ & $* * *$ & $\begin{array}{l}-47.187 \\
{[6.057]}\end{array}$ & $* * *$ & $\begin{array}{l}-- \\
--\end{array}$ & & $\begin{array}{l}-42.269 \\
{[6.597]}\end{array}$ & $* * *$ \\
\hline DynDumi, $t^{*} L L P i,(t-1)$ & $\begin{array}{c}-0.042 \\
{[0.058]}\end{array}$ & & $\begin{array}{c}0.007 \\
{[0.057]}\end{array}$ & & $\begin{array}{c}-0.042 \\
{[0.056]}\end{array}$ & & $\begin{array}{c}-0.202 \\
{[0.063]}\end{array}$ & $* * *$ & $\begin{array}{l}-0.098 \\
{[0.065]}\end{array}$ & \\
\hline DynDumi, $t^{*} C R A R i,(t-1)$ & $\begin{array}{l}-1.030 \\
{[0.348]}\end{array}$ & $* * *$ & $\begin{array}{c}-0.429 \\
{[0.346]}\end{array}$ & & $\begin{array}{c}-1.03 \\
{[0.339]}\end{array}$ & $* * *$ & $\begin{array}{c}-2.105 \\
{[0.898]}\end{array}$ & $* * *$ & $\begin{array}{c}-0.914 \\
{[0.353]}\end{array}$ & $* * *$ \\
\hline DynDumi, ${ }^{*}$ EBTPi,t & $\begin{array}{l}11.253 \\
{[1.775]}\end{array}$ & $* * *$ & $\begin{array}{c}7.353 \\
{[1.767]}\end{array}$ & $* * *$ & $\begin{array}{l}11.253 \\
{[1.725]}\end{array}$ & *** & $\begin{array}{c}6.178 \\
{[2.736]}\end{array}$ & $* * *$ & $\begin{array}{c}6.889 \\
{[1.921]}\end{array}$ & *** \\
\hline
\end{tabular}


Table 6.

LLP and Prudential Regulatory Regime Regression (Continued)

\begin{tabular}{|c|c|c|c|c|c|c|c|c|c|c|}
\hline & \multicolumn{2}{|l|}{ (1) } & \multicolumn{2}{|l|}{ (2) } & \multicolumn{2}{|l|}{ (3) } & \multicolumn{2}{|l|}{ (4) } & \multicolumn{2}{|l|}{ (5) } \\
\hline & \multicolumn{2}{|l|}{ OLS } & \multicolumn{2}{|l|}{ YFE } & \multicolumn{2}{|l|}{ BFE } & \multicolumn{2}{|l|}{ RE } & \multicolumn{2}{|l|}{ GMM } \\
\hline \multirow[t]{2}{*}{ DynDumi, $t^{*} \triangle E B T P i,(t-1)$} & \multirow{2}{*}{\multicolumn{2}{|c|}{$\begin{array}{c}0.292 \\
{[0.845]}\end{array}$}} & \multirow{2}{*}{\multicolumn{2}{|c|}{$\begin{array}{c}0.184 \\
{[0.837]}\end{array}$}} & \multirow{2}{*}{\multicolumn{2}{|c|}{$\begin{array}{c}0.292 \\
{[0.821]}\end{array}$}} & \multirow{2}{*}{\multicolumn{2}{|c|}{$\begin{array}{c}-0.385 \\
{[0.997]}\end{array}$}} & \multirow{2}{*}{\multicolumn{2}{|c|}{$\begin{array}{c}0.637 \\
{[0.846]}\end{array}$}} \\
\hline & & & & & & & & & & \\
\hline \multicolumn{11}{|l|}{ c. Bank Control } \\
\hline \multirow[t]{2}{*}{ LNTA } & 3.700 & $* * *$ & 3.637 & $* * *$ & 3.700 & $* * *$ & 23.879 & $* * *$ & 3.715 & *** \\
\hline & \multicolumn{2}{|l|}{$[0.191]$} & \multicolumn{2}{|l|}{ [0.19] } & \multicolumn{2}{|l|}{$[0.186]$} & [1.096] & & \multicolumn{2}{|l|}{$[0.192]$} \\
\hline \multicolumn{11}{|c|}{ d. Country Macroeconomic Controls } \\
\hline \multirow[t]{2}{*}{ PCGDP } & 0.001 & $* * *$ & \multirow{2}{*}{\multicolumn{2}{|c|}{$\begin{array}{c}0.000 \\
{[0.000]}\end{array}$}} & \multirow{2}{*}{\multicolumn{2}{|c|}{$\begin{array}{c}0.001 \\
{[0.000]}\end{array}$}} & \multirow{2}{*}{\multicolumn{2}{|c|}{$\begin{array}{c}0.000 \\
{[0.000]}\end{array}$}} & \multirow{2}{*}{$\begin{array}{c}0.001 \\
{[0.000]}\end{array}$} & \multirow[t]{2}{*}{$* * *$} \\
\hline & {$[0.000]$} & & & & & & & & & \\
\hline \multirow[t]{2}{*}{ PCGDPG } & -3.167 & $* * *$ & 0.355 & $* * *$ & -3.167 & $* * *$ & -3.371 & $* * *$ & -3.440 & *** \\
\hline & [0.099] & & {$[0.150]$} & & [0.097] & & {$[0.101]$} & & {$[0.104]$} & \\
\hline INFL & -2.051 & $* * *$ & -1.509 & $* * *$ & -2.051 & $* * *$ & -2.413 & $* * *$ & -1.869 & *** \\
\hline & {$[0.212]$} & & {$[0.352]$} & & {$[0.206]$} & & {$[0.222]$} & & {$[0.221]$} & \\
\hline e. Country Regulatory $/ \mathrm{L}$ & gal Contr & & & & & & & & & \\
\hline PRIVO & -25.236 & $* * *$ & -1.230 & & -25.236 & $* * *$ & -- & & -24.555 & *** \\
\hline & [4.588] & & [5.184] & & {$[4.460]$} & & -- & & [5.107] & \\
\hline$M C A P$ & 38.455 & $* * *$ & 19.569 & $* * *$ & 38.455 & $* * *$ & -- & & 43.156 & $* * *$ \\
\hline & [7.378] & & {$[7.574]$} & & [7.172] & & -- & & [8.391] & \\
\hline SPREAD & -0.113 & $* * *$ & -0.015 & & -0.113 & $* * *$ & -- & & -0.163 & $* * *$ \\
\hline & {$[0.044]$} & & {$[0.046]$} & & {$[0.043]$} & & -- & & {$[0.046]$} & \\
\hline$P R$ & -14.264 & $* * *$ & -5.053 & * & -14.264 & $* * *$ & -- & & -15.715 & $* * *$ \\
\hline & [2.107] & & [2.967] & & {$[2.048]$} & & -- & & [2.291] & \\
\hline DISCL & 11.693 & & -7.737 & & 11.693 & & -- & & 4.349 & \\
\hline & {$[10.768]$} & & [11.891] & & {$[10.468]$} & & -- & & [11.897] & \\
\hline$E D F$ & -1.254 & $* * *$ & -0.425 & $* * *$ & -1.254 & $* * *$ & -- & & -1.352 & *** \\
\hline & {$[0.066]$} & & {$[0.085]$} & & {$[0.064]$} & & -- & & {$[0.071]$} & \\
\hline Adj. R-sqd. & 0.402 & & 0.413 & & 0.402 & & 0.435 & & 0.403 & \\
\hline
\end{tabular}

C. Impact of Transition in Accounting Norms on LLP

Hypothesis II states that the motivation for earnings management using LLP under various accounting norms are systematically different. We consider the most prevalent rules-based accounting standard as the base case and then include an indicator variable (PrincDum) for the principles-based accounting standard as shown in Equation (3). Table 7 summarizes the regression estimates. Panel B shows that the principles-based dummy variable and interaction terms reveal little change for the panel. In particular, transition from a rules-based to a principlesbased norm does not exhibit a significant difference in the motivation or magnitude of bank earnings management. In general, most estimates yield insignificant coefficients on the indicator variable and interaction terms. 
Table 7.

\section{LLP and Bank Accounting Standards Regression}

This table reports panel regression results following the model as specified in equation (1). The sample period spans from 19992010 with 7,343 banks and a total of 57,967 bank years, in 118 countries. Column (1) presents the regression estimates using pooled ordinary least squares (OLS). Column (2) reports regression estimates using least squares dummy variable (LSDV) with year fixed effects (YFE). Column (3) presents regression estimates using LSDV with bank fixed effects (BFE). Column (4) reports regression panel estimates with random effects (RE). Column (5) reports the panel general method of moments (GMM) estimates using twostep generalized least square (GLS) estimates with White-corrected standard errors. For each variable, the first row corresponds to the coefficient estimate and the second row reports the standard error in parenthesis. Based on two-tailed test statistics, ${ }^{* * * * *},{ }^{* *}$ and * denote $1 \%, 5 \%$, and $10 \%$ levels of significance, respectively. Loan loss provisions $(L L P)$ is the dependent variable. Explanatory variables include the one-period lag of loan loss provision $\left(L L P_{i(t-1)}\right)$, Tier-I required capital $\left(C R A R_{i(t-1)}\right)$, earnings before tax and provisions $\left(E B T P_{i, t}\right)$, change in earnings before tax and provisions $\left(\triangle E B T P_{i,(t-1)}\right)$, natural log of total assets $(L N T A)$ as control for bank size, several country control variables: GDP per capita (PCGDP), GDP per capita growth (PCGDPG), inflation (INFL), and several regulatory/legal variables: accounting disclosure index (DISCL), efficiency of debt enforcement (EDF), property rights (PR), market capitalization (MCAP), privatization (PRIVO), and interest rate spread (SPRD). Both $L L P P_{i+}$ and EBTP are normalized by the one-period lag of $T A$, and $C R A R_{i,(t-1)}$ is normalized by risk-weighted assets (RWA). PCGDP and PCGDPG are measured in US Dollars. PrincDum it is an indicator variable equal to 1 if the accounting standard of a country follows a principles-based standard and 0 otherwise.

\begin{tabular}{|c|c|c|c|c|c|c|c|c|c|c|}
\hline & \multicolumn{2}{|l|}{ (1) } & \multirow{2}{*}{$\frac{(2)}{\text { YFE }}$} & \multicolumn{3}{|c|}{ (3) } & (4) & \multicolumn{3}{|c|}{ (5) } \\
\hline & OLS & & & & BFE & & RE & & GMM & \\
\hline \multirow[t]{2}{*}{ CONS } & 107.926 & $* * *$ & 12.536 & & 107.926 & $* * *$ & -- & & -- & \\
\hline & {$[9.692]$} & & [11.47] & & {$[9.422]$} & & -- & & -- & \\
\hline \multicolumn{11}{|l|}{ a. Bank Characteristics } \\
\hline$L L P i,(t-1) \quad(+)$ & $\begin{array}{c}0.508 \\
{[0.005]}\end{array}$ & $* * *$ & $\begin{array}{c}0.497 \\
{[0.005]}\end{array}$ & $* * *$ & $\begin{array}{c}0.508 \\
{[0.004]}\end{array}$ & $* * *$ & $\begin{array}{c}0.000 \\
{[0.000]}\end{array}$ & $* * *$ & $\begin{array}{c}0.504 \\
{[0.005]}\end{array}$ & $* * *$ \\
\hline CRARi, $(t-1)$ & $\begin{array}{c}-0.091 \\
{[0.011]}\end{array}$ & $* * *$ & $\begin{array}{c}-0.092 \\
{[0.011]}\end{array}$ & $* * *$ & $\begin{array}{c}-0.091 \\
{[0.010]}\end{array}$ & $* * *$ & $\begin{array}{c}0.001 \\
{[0.000]}\end{array}$ & $* * *$ & $\begin{array}{c}-0.089 \\
{[0.011]}\end{array}$ & $* * *$ \\
\hline EBTPi,t & $\begin{array}{c}0.543 \\
{[0.068]}\end{array}$ & $* * *$ & $\begin{array}{c}0.580 \\
{[0.067]}\end{array}$ & $* * *$ & $\begin{array}{c}0.543 \\
{[0.066]}\end{array}$ & $* * *$ & $\begin{array}{c}0.006 \\
{[0.000]}\end{array}$ & $* * *$ & $\begin{array}{c}0.524 \\
{[0.068]}\end{array}$ & *** \\
\hline$\triangle E B T P i,(t-1)$ & $\begin{array}{c}-0.03 \\
{[0.139]}\end{array}$ & & $\begin{array}{c}0.051 \\
{[0.137]}\end{array}$ & & $\begin{array}{c}-0.03 \\
{[0.135]}\end{array}$ & & $\begin{array}{c}0.002 \\
{[0.000]}\end{array}$ & $* * *$ & $\begin{array}{c}-0.019 \\
{[0.138]}\end{array}$ & \\
\hline \multicolumn{11}{|c|}{ b. Impact of Principles-Based Standard } \\
\hline PrincDumi,t & $\begin{array}{c}-59.484 \\
{[30.213]}\end{array}$ & $*$ & $\begin{array}{c}3.390 \\
{[30.777]}\end{array}$ & & $\begin{array}{c}-59.484 \\
{[29.371]}\end{array}$ & $*$ & -- & & $\begin{array}{l}-66.383 \\
{[31.939]}\end{array}$ & ** \\
\hline PrincDumi, $t^{*} L L P i,(t-1)$ & $\begin{array}{c}-0.115 \\
{[0.095]}\end{array}$ & & $\begin{array}{c}0.068 \\
{[0.094]}\end{array}$ & & $\begin{array}{c}-0.115 \\
{[0.092]}\end{array}$ & & $\begin{array}{c}0.003 \\
{[0.001]}\end{array}$ & $* * *$ & $\begin{array}{c}-0.130 \\
{[0.105]}\end{array}$ & \\
\hline PrincDumi, $t^{*} C R A R i,(t-1)$ & $\begin{array}{c}0.208 \\
{[0.257]}\end{array}$ & & $\begin{array}{c}-0.043 \\
{[0.257]}\end{array}$ & & $\begin{array}{c}0.208 \\
{[0.250]}\end{array}$ & & $\begin{array}{c}0.131 \\
{[0.872]}\end{array}$ & & $\begin{array}{c}0.247 \\
{[0.273]}\end{array}$ & \\
\hline PrincDumi, $t^{*}$ EBTPi,t & $\begin{array}{c}1.360 \\
{[1.912]}\end{array}$ & & $\begin{array}{c}0.229 \\
{[1.894]}\end{array}$ & & $\begin{array}{c}1.360 \\
{[1.858]}\end{array}$ & & $\begin{array}{c}3.446 \\
{[0.534]}\end{array}$ & & $\begin{array}{c}1.424 \\
{[1.976]}\end{array}$ & \\
\hline PrincDumi, $t^{*} \triangle E B T P i,(t-1)$ & $\begin{array}{c}1.166 \\
{[0.837]}\end{array}$ & & $\begin{array}{c}0.662 \\
{[0.829]}\end{array}$ & & $\begin{array}{c}1.166 \\
{[0.813]}\end{array}$ & & $\begin{array}{c}0.291 \\
{[0.182]}\end{array}$ & & $\begin{array}{r}1.236 \\
{[0.837]}\end{array}$ & \\
\hline \multicolumn{11}{|l|}{ c. Bank Control } \\
\hline LNTA & $\begin{array}{c}3.810 \\
{[0.194]}\end{array}$ & $* * *$ & $\begin{array}{c}3.758 \\
{[0.192]}\end{array}$ & $* * *$ & $\begin{array}{c}3.810 \\
{[0.188]}\end{array}$ & $* * *$ & $\begin{array}{c}1.169 \\
{[0.000]}\end{array}$ & $* * *$ & $\begin{array}{c}3.851 \\
{[0.194]}\end{array}$ & $* * *$ \\
\hline \multicolumn{11}{|c|}{ d. Country Macroeconomic Controls } \\
\hline PCGDP & $\begin{array}{c}0.001 \\
{[0.000]}\end{array}$ & $* * *$ & $\begin{array}{c}0.000 \\
{[0.000]}\end{array}$ & & $\begin{array}{c}0.001 \\
{[0.000]}\end{array}$ & $* * *$ & $\begin{array}{c}0.000 \\
{[0.000]}\end{array}$ & $* * *$ & $\begin{array}{c}0.001 \\
{[0.000]}\end{array}$ & $* * *$ \\
\hline PCGDPG & $\begin{array}{c}-3.202 \\
{[0.098]}\end{array}$ & $* * *$ & $\begin{array}{c}0.328 \\
{[0.149]}\end{array}$ & ** & $\begin{array}{c}-3.202 \\
{[0.096]}\end{array}$ & $* * *$ & $\begin{array}{c}0.001 \\
{[0.000]}\end{array}$ & $* * *$ & $\begin{array}{l}-3.506 \\
{[0.103]}\end{array}$ & $* * *$ \\
\hline INFL & $\begin{array}{l}-1.943 \\
{[0.207]}\end{array}$ & $* * *$ & $\begin{array}{l}-1.645 \\
{[0.339]}\end{array}$ & $* * *$ & $\begin{array}{l}-1.943 \\
{[0.201]}\end{array}$ & $* * *$ & $\begin{array}{c}0.009 \\
{[0.000]}\end{array}$ & $* * *$ & $\begin{array}{c}-1.66 \\
{[0.215]}\end{array}$ & $* * *$ \\
\hline
\end{tabular}


Table 7.

LLP and Bank Accounting Standards Regression (Continued)

\begin{tabular}{|c|c|c|c|c|c|c|c|c|c|}
\hline & \multicolumn{2}{|l|}{ (1) } & \multicolumn{2}{|l|}{ (2) } & \multicolumn{2}{|l|}{ (3) } & (4) & \multicolumn{2}{|l|}{ (5) } \\
\hline & \multicolumn{2}{|l|}{ OLS } & \multicolumn{2}{|l|}{ YFE } & \multicolumn{2}{|l|}{ BFE } & RE & \multicolumn{2}{|l|}{ GMM } \\
\hline \multicolumn{10}{|c|}{ e. Country Regulatory/Legal Controls } \\
\hline \multirow[t]{2}{*}{ PRIVO } & -32.570 & $* * *$ & -2.765 & & -32.570 & *** & -- & -32.082 & $* * *$ \\
\hline & [4.692] & & {$[5.278]$} & & [4.562] & & -- & {$[5.253]$} & \\
\hline \multirow[t]{2}{*}{ MCAP } & 49.069 & $* * *$ & 25.13 & $* * *$ & 49.069 & $* * *$ & -- & 49.773 & $* * *$ \\
\hline & [7.475] & & [7.633] & & [7.266] & & -- & [8.495] & \\
\hline \multirow[t]{2}{*}{$S P R D$} & -0.151 & $* * *$ & -0.073 & & -0.151 & $* * *$ & -- & -0.212 & $* * *$ \\
\hline & {$[0.045]$} & & {$[0.046]$} & & [0.043] & & -- & {$[0.046]$} & \\
\hline \multirow[t]{2}{*}{$P R$} & -9.800 & $* * *$ & 2.007 & & -9.800 & $* *$ & -- & -8.253 & $* * *$ \\
\hline & [1.951] & & [2.632] & & [1.897] & & -- & [2.125] & \\
\hline \multirow[t]{2}{*}{ DISCL } & -1.858 & & -30.207 & * & -1.858 & & -- & -7.440 & \\
\hline & [10.935] & & [12.283] & & [10.631] & & -- & [12.289] & \\
\hline \multirow[t]{2}{*}{$E D F$} & -1.431 & $* * *$ & -0.526 & $* * *$ & -1.431 & $* * *$ & -- & -1.577 & \\
\hline & {$[-0.070]$} & & [0.085] & & {$[0.068]$} & & -- & {$[0.077]$} & \\
\hline Adj. R-sqd. & 0.402 & & 0.414 & & 0.402 & & & 0.403 & \\
\hline
\end{tabular}

D. Combined Effect of Changes in Prudential Rules and Change in Accounting Standards Hypothesis III states that the joint impact of changes in prudential rules and accounting norms will yield a change in the motivation for bank LLP earnings management. We analyze the impact of a joint change in prudential regime and accounting standards by including both interaction variables as shown in Equation (4). Table 8 reports the regression estimates of the joint change in standards. Results show that banks under a principles-based accounting standard are likely to exhibit lower levels of earnings management, as expressed by the negative fixed effects coefficient in Panel D compared to their rules-based accounting standard counterparts. Moreover, banks under the dynamic prudential regime are, in general, more likely to maintain additional levels of provisioning, as shown by the positive fixed effects coefficient in Panel E, compared to the pro-cyclical regimes. Overall, we find that a (simultaneous) joint change, as captured through the two interaction terms in panel $\mathrm{F}$, on the motivation for earnings management of LLP is not significantly different from banks with no change in policies. More aptly, the motives and magnitude of the effects of earnings management via LLP remains largely unchanged for the panel under a joint transition. 
Table 8 .

\section{LLP and Joint Change in Prudential Regulation and Accounting Standards Regression}

This table reports panel regression results following the model as specified in equation (1). The sample period spans from 19992010 with 7,343 banks and a total of 57,967 bank years, in 118 countries. Column (1) presents the regression estimates using pooled ordinary least squares (OLS). Column (2) reports regression estimates using least squares dummy variable (LSDV) with year fixed effects (YFE). Column (3) presents regression estimates using LSDV with bank fixed effects (BFE). Column (4) reports regression panel estimates with random effects (RE). Column (5) reports the panel general method of moments (GMM) estimates using twostep generalized least square (GLS) estimates with White-corrected standard errors. For each variable, the first row corresponds to the coefficient estimate and the second row reports the standard error in parenthesis. Based on two-tailed test statistics, ${ }^{* * *},{ }^{* *}$, and * denote $1 \%, 5 \%$, and $10 \%$ levels of significance, respectively. Loan loss provisions (LLP) is the dependent variable. Explanatory variables include the one-period lag of loan loss provision $\left(\operatorname{LLP}_{\mathrm{i},(t-1)}\right)$, Tier-I required capital $\left(\mathrm{CRAR}_{\mathrm{i},(t-1)}\right)$, earnings before tax and provisions $\left(\mathrm{EBTP}_{\mathrm{it}}\right)$, change in earnings before tax and provisions $\left(\triangle \mathrm{EBTP}_{\mathrm{i}(\mathrm{t}-1)}\right)$, natural log of total assets (LNTA) as control for bank size, several country control variables: GDP per capita (PCGDP), GDP per capita growth (PCGDPG), inflation (INFL), and several regulatory/legal variables: accounting disclosure index (DISCL), efficiency of debt enforcement (EDF), property rights (PR), market capitalization (MCAP), privatization (PRIVO), and interest rate spread (SPRD). Both LLP ${ }_{i+t}$ and EBTP ${ }_{i+1}$ are normalized by the one-period lag of TA, and CRAR itt-1) $_{\text {in }}$ is normalized by risk-weighted assets (RWA). PCGDP and PCGDPG are measured in US Dollars. DynDum is an indicator variable equal to 1 if the prudential regulatory regime of a country follows dynamic provisioning and 0 otherwise. PrincDum ${ }_{\mathrm{i}, \mathrm{t}}$ is an indicator variable equal to 1 if the accounting standard of a country follows a principles-based standard and 0 otherwise.

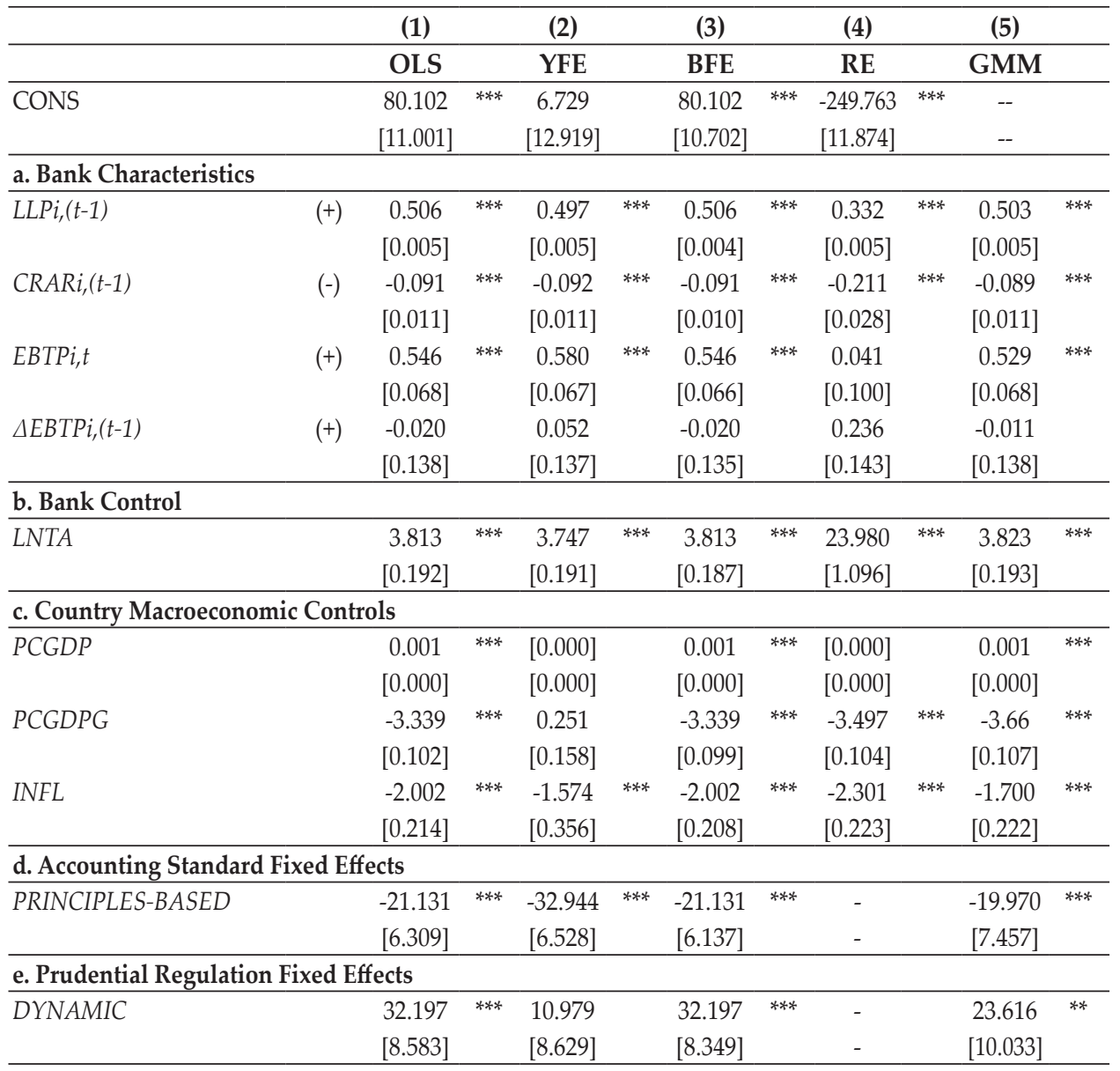


Table 8.

LLP and Joint Change in Prudential Regulation and Accounting Standards Regression (Continued)

\begin{tabular}{|c|c|c|c|c|c|c|c|c|c|}
\hline & \multicolumn{2}{|l|}{ (1) } & \multicolumn{2}{|l|}{$(2)$} & \multicolumn{2}{|l|}{ (3) } & \multirow{2}{*}{$\begin{array}{l}\text { (4) } \\
\text { RE }\end{array}$} & \multicolumn{2}{|l|}{ (5) } \\
\hline & OLS & & YFE & & BFE & & & GMM & \\
\hline \multicolumn{10}{|c|}{ f. Impact of Changes in both Standards } \\
\hline \multirow[t]{2}{*}{ DynDumi, $t^{*}$ PrincDumi, $t^{*} L L P i,(t-1)$} & 0.285 & & 0.278 & & 0.285 & * & -0.272 & 0.295 & * \\
\hline & {$[0.174]$} & & {$[0.172]$} & & [0.169] & & {$[0.222]$} & {$[0.175]$} & \\
\hline \multirow[t]{2}{*}{ DynDumi, $t^{*}$ PrincDumi, $t^{*}$ CRARi, $(t-1)$} & 0.194 & & 0.154 & & 0.194 & & 0.464 & 0.153 & \\
\hline & {$[0.384]$} & & {$[0.381]$} & & {$[0.373]$} & & [1.004] & {$[0.389]$} & \\
\hline \multirow[t]{2}{*}{ DynDumi, $t^{*}$ PrincDumi, $t^{*}$ EBTPi,t } & 0.245 & & 0.047 & & 0.245 & & 1.024 & 0.165 & \\
\hline & {$[2.142]$} & & [2.123] & & {$[2.084]$} & & [2.893] & [2.157] & \\
\hline \multirow[t]{2}{*}{ DynDumi, $t^{*}$ PrincDumi, $t^{*} \Delta E B T P i,(t-1)$} & 0.532 & & 0.398 & & 0.532 & & -0.152 & 0.490 & \\
\hline & {$[0.857]$} & & {$[0.850]$} & & {$[0.834]$} & & [1.044] & {$[0.857]$} & \\
\hline \multicolumn{10}{|c|}{ g. Country Regulatory/Legal Controls } \\
\hline \multirow[t]{2}{*}{ PRIVO } & -36.339 & $* * *$ & -5.984 & & -36.339 & $* * *$ & -- & -34.528 & $* * *$ \\
\hline & {$[4.722]$} & & {$[5.478]$} & & {$[4.593]$} & & -- & [5.241] & \\
\hline \multirow[t]{2}{*}{ MCAP } & 29.471 & $* * *$ & 22.848 & $* * *$ & 29.471 & $* * *$ & -- & 30.864 & $* * *$ \\
\hline & [7.767] & & [7.809] & & [7.555] & & -- & [8.859] & \\
\hline \multirow[t]{2}{*}{ SPREAD } & -0.169 & $* * *$ & -0.073 & & -0.169 & $* * *$ & -- & -0.228 & $* * *$ \\
\hline & [0.045] & & [0.047] & & {$[0.043]$} & & -- & [0.046] & \\
\hline \multirow[t]{2}{*}{$P R$} & -1.369 & & 3.294 & & -1.369 & & -- & -1.385 & \\
\hline & [2.487] & & [3.213] & & {$[2.420]$} & & -- & [2.781] & \\
\hline \multirow[t]{2}{*}{ DISCL } & 37.163 & $* * *$ & -18.027 & & 37.163 & $* * *$ & -- & 29.306 & ** \\
\hline & [11.874] & & [14.181] & & [11.551] & & -- & [13.146] & \\
\hline \multirow[t]{2}{*}{$E D F$} & -1.658 & $* * *$ & -0.603 & & -1.658 & $* * *$ & -- & -1.773 & $* * *$ \\
\hline & {$[0.076]$} & & [0.102] & & {$[0.074]$} & & -- & {$[0.084]$} & \\
\hline Adj. R-sqd. & 0.403 & & 0.414 & & 0.403 & & 0.435 & 0.404 & \\
\hline
\end{tabular}

\section{CONCLUDING REMARKS}

Prior literature regarding the banking industry finds that managers often use their own discretion in the form of earnings management when estimating LLP. Explanations for such behavior have found broad empirical support in the income smoothing, capital management, and earnings signaling hypotheses. We revisit these three hypotheses for a large international sample of banking data that includes 7,343 commercial banks in 118 countries. We analyze the differences as to why bank managers would use $L L P$ as an earnings management tool in regards to changes in accounting standards and changes in prudential regulation. Results are robust to econometric estimation and modeling specification, as we control bank asset size, country macroeconomic factors, and regulatory factors throughout the analysis.

Our findings support the notion that, in general, bank managers engage in earnings management of LLP for two motives: income smoothing and managing capital adequacy. We find no evidence supporting the earnings signaling argument. Evidence supporting a differential motivation for earnings management based on a change in regulatory regimes or accounting standards for the panel is weak. 
However, we do find that when a country transitions from pro-cyclical rules to dynamic provisioning rules, bank managers pursuing an income smoothing motive will generally maintain a larger amount for $L L P$. In contrast, bank managers pursuing capital management motives will set aside a slightly smaller amount of LLP.

Moreover, we note that if a country undergoes a (simultaneous) change in prudential regulation and accounting standards, the combined impact on the motivation for $L L P$ earnings management is statistically insignificant. We document that banks under a principles-based accounting standard generally exhibit weaker earnings management when compared to their rules-based counterparts. Comparably, banks under the dynamic prudential regime are, in general, more likely to maintain additional levels of LLP compared to their procyclical opposites.

\section{REFERENCES}

Ahmed, A.S., Takeda, C. and Thomas, S. (1999). Bank Loan Loss Provisions: A Reexamination of Capital Management, Earnings Management and Signaling Effects. Journal of Accounting Economics, 28, 1-25.

Anandarajan, A., Hasan, I. and Lozano-Vivas, A. (2003). The Role of Loan Loss Provisions in Earnings Management, Capital Management, and Signaling: The Spanish Experience. Advances in International Accounting, 16, 45-65.

Balla, E. and McKenna, A. (2009). Dynamic Provisioning: A Countercyclical Tool for Loan Loss Reserves. Economic Quarterly, 95, 383-418.

Bartov, E., Goldberg, S.R., and Kim, M. (2005). Comparative Value Relevance Among German, US, and International Accounting Standards: A German Stock Market Perspective. Journal of Accounting, Auditing E Finance, 20, 95-119.

Beaver, W.H., and Engle, E.E. (1996). Discretionary Behavior with Respect to Allowance for Loan Losses and the Behavior of Securities Prices. Journal of Accounting and Economics, 22, 177-206.

Beest, F.V. (2009). Rules-Based and Principles-Based Accounting Standards and Earnings Management. Nijmegen Center for Economics (NiCE) Working Paper 09-114, available at: https://repository.ubn.ru.nl//bitstream/ handle/2066/74890/74890.pdf

Bikker, J.A. and Metzemakers, P.A.J. (2005). Bank Provisioning Behavior and Procyclicality. Journal of International Financial Markets, Institutions and Money, 15, 141-157.

Bouvatier, V. and Lepetit, L. (2008). Banks' Pro-Cyclical Behavior: Does Provisioning Matter? Journal of International Financial Markets, Institutions and Money, 18, 513-526.

Bouvatier, V. and Lepetit, L. (2012). Effects of Loan Loss Provisions on Growth in Bank Lending: Some International Comparisons. International Economics, 132, 91-116.

Bouvatier, V., Lepetit, L., and Strobel, F. (2014). Bank Income Smoothing, Ownership Concentration and the Regulatory Environment. Journal of Banking and Finance, 41, 253-270. 
Burroni, M., Quagliariello, M., Sabatini, E. and Tola, V. (2009). Dynamic Provisioning: Rationale, Functioning, and Prudential Treatment. Bank of Italy Research Paper Series No.57, available at: https://papers.ssrn.com/sol3/papers.cfm?abstract_ id $=1697575$

Capkun, V., Jeny, A.C., Jeanjean, T. and Weiss, L.A. (2010). Setting the Bar: Earnings Management During a Change in Accounting Standards. Financial Reporting ESSEC-KPMG Centre Working Paper, available at: https://hal.archivesouvertes.fr/hal-00675060/0

Carbó-Valverde, S. and Rodríguez-Fernández, F. (2010). Counter-Cyclical Provisions, Managerial Discretion and Loan Growth: The Case of Spain. Working Paper, available at : http://citeseerx.ist.psu.edu/viewdoc/ download?doi=10.1.1.644.5534\&rep=rep1\&type=pdf

Chan-Lau, J. A. (2012). Do Dynamic Provisions Enhance Bank Solvency and Reduce Credit Procyclicality? A Study of the Chilean Banking System. Journal of Banking Regulation, 13, 178-188.

Cohen, D.A., Dey, A., and Lys, T.Z. (2008). Real and Accrual-Based Earnings Management in the Pre- and Post-Sarbanes-Oxley Periods. The Accounting Review, 83, 757-787.

Das, A., and Ghosh, S. (2007). Determinants of Credit Risk in Indian State-Owned Banks: An Empirical Investigation. Economic Issues, 12, 27-46.

Djankov, S., McLiesh, C. and Shleifer, A. (2007). Private Credit in 129 Countries. Journal of Financial Economics, 84, 299-329.

Fan, J. and Wong, T. (2002). Corporate Ownership Structure and the Informativeness of Accounting Earnings in East Asia. Journal of Accounting and Economics, 33, 401-425.

Fonseca, A.R. and González, F. (2008). Cross-Country Determinants of Bank Income Smoothing by Managing Loan-Loss Provisions. Journal of Banking and Finance, 32, 217- 228.

Gebhardt, G. and Novotny-Farkas, Z. (2011). Mandatory IFRS Adoption and Accounting Quality of European Banks. Journal of Business and Finance Accounting, 38, 289-333.

Hasan, I. and Wall, L. (2004). Determinants of the Loan Loss Allowance: Some Cross-Country Comparisons. Financial Review, 39, 129-152.

Hausman, J. (1978). Specification Tests in Econometrics. Econometrica, 46, 12511271.

Hung, M. and Subramanyam, K.R. (2007). Financial Statement Effects of Adopting International Accounting Standards: The Case of Germany. Review of Accounting Studies, 12, 623-657.

Laeven, L. and Majnoni, G. (2003). Loan Loss Provisioning and Economic Slowdowns: Too Much, Too Late? Journal of Financial Intermediation, 12, 178197.

La Porta, R, Lopez-de-Silanes, F., and Shleifer, A. (2008). The Economic Consequences of Legal Origins. Journal of Economic Literature, 46, 285-332.

La Porta, R., Lopez-de-Silanes, F., Shleifer, A. and Vishny, R. (1997). Legal Determinants of External Finance. Journal of Finance, 52, 1131-1150.

Panetta, F., Angelini, P., Albertazzi, U., Columba, F., Cornacchia, W., DiCesare, A., Pilati, A. Salleo, C., and Santini, G. (2009). Financial Sector Pro-Cyclicality: 
Lessons from The Crisis. Banca d'Italia Occasional Papers No. 44, available at: https://papers.ssrn.com/sol3/papers.cfm?abstract_id=1479499.

Pérez, D., Salas-Fumás, V. and Saurina, J. (2011). Do Dynamic Provisions Reduce Income Smoothing Using Loan Loss Provisions? Bank of Spain Working Paper 1118, available at: https://www.bde.es/f/webbde/SES/Secciones/Publicaciones/ PublicacionesSeriadas/DocumentosTrabajo/11/Fich/dt1118e.pdf

Psaros, J. and Trotman, K.T. (2004). The Impact of the Type of Accounting Standards on Preparers' Judgments. Abacus, 40, 76-93.

Wahlen, J. (1994). The Nature of Information in Commercial Bank Loans Loss Disclosures. The Accounting Review, 69, 455-478.

Wezel, T. (2010). Dynamic Loan Loss Provisions in Uruguay: Properties, Shock Absorption Capacity and Simulations Using Alternative Formulas. International Monetary Fund Working Paper No. 10/125.

Zhou, H., Xiong, Y. and Ganguli, G. (2010). Accounting Standards and Earnings Management: Evidence from an Emerging Market. University of Texas Working Paper, available at: https://www.researchgate.net/profile/haiyan_zhou4/ publication/241420854_accounting_standards_and_earnings_management_ evidence_from_an_emerging_market/links/02e7e52e3ec0b0932b000000/ accounting-standards-and-earnings-management-evidence-from-an-emergingmarket.pdf. 
This page is intentionally left blank 